OPEN ACCESS

Edited by:

Juscelino Tovar,

Lund University, Sweden

Reviewed by:

Oswaldo Hernandez-Hernandez, Institute of Food Science Research

(CIAL), Spain

Cecilia Tullberg,

Lund University, Sweden

Tomy J. Gutiérrez,

Consejo Nacional de Investigaciones

Científicas y Técnicas

(CONICET), Argentina

*Correspondence:

Rotimi E. Aluko

Rotimi.Aluko@umanitoba.ca

Specialty section:

This article was submitted to

Food Chemistry,

a section of the journal

Frontiers in Nutrition

Received: 08 September 2021

Accepted: 12 October 2021

Published: 08 November 2021

Citation:

Oluwagunwa $O A$, Alashi $A M$ and

Aluko RE (2021) Inhibition of the in

vitro Activities of $\alpha$-Amylase and

Pancreatic Lipase by Aqueous

Extracts of Amaranthus viridis, Solanum macrocarpon and Telfairia

occidentalis Leaves.

Front. Nutr. 8:772903.

doi: 10.3389/fnut.2021.772903

\section{Inhibition of the in vitro Activities of $\alpha$-Amylase and Pancreatic Lipase by Aqueous Extracts of Amaranthus viridis, Solanum macrocarpon and Telfairia occidentalis Leaves}

\author{
Olayinka A. Oluwagunwa ${ }^{1}$, Adeola M. Alashi ${ }^{1}$ and Rotimi E. Aluko ${ }^{1,2 *}$ \\ ${ }^{1}$ Department of Food and Human Nutritional Sciences, University of Manitoba, Winnipeg, MB, Canada, ${ }^{2}$ The Richardson \\ Center for Functional Foods and Nutraceuticals, University of Manitoba, Winnipeg, MB, Canada
}

Inhibition of digestive enzymes such as $\alpha$-amylase and pancreatic lipase (PL) is a promising therapeutic strategy for the treatment and management of chronic health conditions such as diabetes and obesity. Therefore, the aim of this work was to determine the enzyme inhibitory activity of polyphenol-rich aqueous extracts of Amaranthus viridis (AV), Solanum macrocarpon (SM) and Telfairia occidentalis (TO) leaves, which were harvested from plants produced using multiple urea fertilizer doses $(0-80 \mathrm{~kg} \mathrm{~N} / \mathrm{ha})$. Fertilizer application was applied at two time points (at planting or 2 weeks after seedling emergence). Leaf extracts were obtained using aqueous extraction (1:20, leaves:water) for $4 \mathrm{~h}$ at $60^{\circ} \mathrm{C}$ followed by centrifugation and freeze-drying of the supernatant. Results showed that the extracts inhibited $\alpha$-amylase, and pancreatic lipase dose-dependently with TO extracts having significantly $(p<0.05)$ higher inhibitory activities for both enzymes. Fluorescence intensity and circular dichroism spectra in the presence and absence of leaf extracts indicate significant changes to the enzyme protein secondary and tertiary conformations. We conclude that the leaf extracts, especially from TO are potential agents for reducing calorie intake as a preventive or treatment tool against chronic diseases such as diabetes and obesity.

Keywords: leaf extracts, polyphenolic compounds, $\alpha$-amylase, pancreatic lipase, enzyme inhibition, fluorescence intensity, circular dichroism

\section{INTRODUCTION}

Polyphenol-rich plant foods have been reported to induce insulin-like effects and can act as good inhibitors of enzymes such as $\alpha$-amylase and pancreatic lipase associated with type 2 diabetes, obesity and lipid peroxidation (1). In order to control the function of these enzymes, larger plants, animals and microorganisms have been found to produce large number of different enzyme protein inhibitors of these enzymes. These enzyme inhibitors block the enzyme's active center thus preventing the rate at which polysaccharides are digested (2-4). Different in vitro and in vivo studies have shown that dietary phenolic compounds have many beneficial properties in maintaining human health (5). Studies have found that phenolic compounds are good inhibitors of $\alpha$-amylase, and pancreatic lipase (6-9). The ability of plant-derived products such as from oats (10), berry (11) 
and tea (12) to inhibit these enzymes are associated with the phenolic content and other flavonoid components (13). One of the major ways of controlling diabetes is by inhibiting a carbohydrate-hydrolyzing enzyme such as $\alpha$-amylase, which reduces the amount of glucose available for absorption into the body from the small intestine $(14,15)$. $\alpha$-amylase cleaves $\alpha$ 1,4 glycosidic bonds to convert complex dietary carbohydrates like starch into oligosaccharides and disaccharides, which are further broken down into absorbable monosaccharides such as glucose and fructose by glucosidases $(16,17)$. Another enzyme of utmost importance in diabetes is pancreatic lipase (PL), which digests lipids, mainly dietary triacyl-glycerides, which are broken down into monoglycerides and free fatty acids that can be readily absorbed into the blood circulatory system $(18,19)$. PL inhibition reduces the absorption of fat in the small intestine thus contributing to reduced calorie intake and prevention of excessive body weight gain (20). Therefore, inhibition of $\alpha$ amylase and PL activities is a known strategy to prevent the breakdown of dietary polysaccharides and fats, which leads to reductions in the absorption of simple sugars and lipids (21, 22 ). With the global increase in the occurrence of diabetes and obesity, inhibition of these enzymes is of utmost importance in disease management (23).

Fluorescence emission spectroscopy is a useful tool to measure minute structural changes in protein structure, especially upon binding to small molecule ligands such as enzyme inhibitors. This is because aromatic amino acids like Trp, Tyr, and Phe can emit fluorescence spectra with maximum values at 350,303, and $280 \mathrm{~nm}$, respectively, when they are excited in the UV region (24). However, the emission wavelengths reflect conformational changes in the protein, which are dependent on exposure of the aromatic amino acids to the hydrophilic environment (25). For example, decreases in fluorescence intensity are indications of protein unfolding and increased exposure of aromatic amino acids to a more polar environment while increases suggest shift to non-polar environments $(24,26)$. Circular dichroism (CD) measures the secondary and tertiary conformations of proteins, which can be used to evaluate relationships of enzyme protein structure to catalytic activity especially in the presence of inhibitors. The CD signal of each protein depends on the number and proximity of the aromatic amino acid residues to each other, degree of H-bonding and presence of disulfide bonds (27).

Foods are well known sources of enzyme inhibitory compounds, but their levels could be dependent on agronomic practices, which are critical for defining crop productivity, nutrient composition, and food availability. Therefore, in order to ensure food supply and increase crop productivity, the positive effect of mineral fertilizers cannot be overemphasized $(28,29)$. The use of fertilizer micro-dosing gives promising results in terms of crop productivity and farmers' income when compared to the traditional fertilizer broadcasting method. Fertilizer micro-dosing is a method of fertilizer application in small quantities at an optimal depth and distance around the target crop such as leafy vegetables $(29,30)$ and maize (31) either during the time of planting or some weeks after planting. Water is a universal solvent with numerous advantages as a green extraction solvent because it is cheap, non-flammable, non-toxic, environmentally friendly, and prevent pollution when compared to organic solvents (32). Moreover, the use of water enhances solubility of the extracted polyphenolic compounds within the mainly aqueous-based in vitro assay reagents and also in the aqueous gastrointestinal tract when ingested, which ensures bioavailability. Although the organic leaf extract of fluted pumpkin (33), and eggplant (34) have been reported to inhibit $\alpha$-amylase, there is paucity of information in literature on the inhibition of $\alpha$-amylase and PL by aqueous extracts of these plants as well as the consequence of phenolic interactions on enzyme structural conformation. Therefore, the aim of this work was to determine the effect of fertilizer microdosing on the in vitro inhibitory activities of aqueous extracts of Amaranthus viridis (AV), Telfairia occidentalis (TO) and Solanum marcrocarpon (SM) leaves against $\alpha$-amylase, and PL. The effects of these leaf extracts on the structural conformations of $\alpha$-amylase and PL were also measured using circular dichroism (CD) and intrinsic fluorescence to determine possible means by which the phenolic compounds attenuate catalysis rate. AV, SM, and TO were chosen for this study because they are one of the most under-utilized indigenous culinary herbs in Nigeria, popularly grown among local farmers. They are commonly consumed by indigenous people as blood boosters, to treat infertility, as anti-inflammatory, antidiabetic and antiviral agents. Moreover, AV, SM, and TO produce a range of polyphenolic compounds including caffeic acid, rutin, and myricetin (30, 35, 36).

\section{MATERIALS AND METHODS}

\section{Materials and Chemicals}

Porcine pancreas PL (26.9 units/mg protein) and $\alpha$-amylase Type VI-B (25 units/mg solid) were purchased from Alfa Aesar (Tewksbury, MA, USA) and Sigma Aldrich (St. Louis, MO, USA), respectively, while other analytical grade reagents were from Fisher Scientific (Oakville, ON, Canada). The plants (AV, TO, and SM) were produced at the Micro-Veg Project experimental farm, located at the Obafemi Awolowo University, Ile-Ife, Osun State, Nigeria. The plants were grown using mineral fertilizer application according to the fertilizer micro-dosing technology ( $\sim 0.1-0.5 \mathrm{~cm}$ deep) with a randomized complete block design and five nitrogen (urea) fertilizer doses, which were replicated four times as follows: $0,20,40,60$, and $80 \mathrm{~kg}$ of urea/ha. Cow manure was used as a base organic fertilizer at $5 \mathrm{t} / \mathrm{ha}$ on experimental plots $(2 \mathrm{~m} \times 3 \mathrm{~m})$ that received urea at 20, 40, and $60 \mathrm{~kg} \mathrm{~N} / \mathrm{ha}$. In contrast, the plots that received $80 \mathrm{~kg} \mathrm{~N} / \mathrm{ha}$ urea did not contain organic fertilizer while the $0 \mathrm{~kg} \mathrm{~N} / \mathrm{ha}$ plots received only the organic fertilizer but not urea. The urea fertilizer was applied to each plot during planting (T1) or 2 weeks after emergence of seedlings (T2) to obtain the following samples: 0-T1, 0-T2, 20-T1, 20-T2, 40-T1, 40-T2, 60-T1, 60-T2, 80-T1, and 80-T2. Twenty-five days after seedlings emerged, the leaves were harvested, rinsed in potable water, destalked, and dried using an air cabinet at $60^{\circ} \mathrm{C}$ for $8 \mathrm{~h}$. The dried leaves were milled into fine powder using a Marlex Excella dry mill (Marlex Appliances PVT, Daman, India) followed by storage at $-20^{\circ} \mathrm{C}$. 


\section{Preparation of Aqueous Extracts Containing Free Polyphenols}

Free water-soluble polyphenolic compounds were extracted using the method of Olarewaju et al. (30). Dried leaf powders were mixed with 20 volumes of distilled water at $60^{\circ} \mathrm{C}$ for $2 \mathrm{~h}$ under constant stirring. After cooling to $25^{\circ} \mathrm{C}$, the mixture was centrifuged at $10,000 \mathrm{x}$ g for $30 \mathrm{~min}$ and supernatant passed through a cheese cloth. The residue was re-extracted and centrifuged using same conditions to obtain a second supernatant. The two supernatants were pooled together, concentrated using a vacuum rotatory evaporator at $60^{\circ} \mathrm{C}$, freeze-dried and the extract powder stored at $-20^{\circ} \mathrm{C}$. We have previously reported that the dried leaf extracts are composed mainly of polyphenols with total polyphenolic content values in the range of $460-611 \mathrm{mg}$ gallic acid equivalent/g where rutin, myricetin, and caffeic acid were detected as the major compounds (30).

\section{$\alpha$-Amylase Inhibition Assay}

The $\alpha$-amylase inhibitory activity of leaf extracts was determined using the method described by Karakaya et al. (37) with slight modifications. The enzyme substrate was prepared by bringing to boil $100 \mathrm{~mL}$ of distilled water in a $250 \mathrm{~mL}$ beaker on a hot plate and then added to a smooth paste of potato starch followed by stirring until it is dissolved. The starch solution was then allowed to cool down to room temperature before it is used for the enzyme assay. The dried leaf extracts were dissolved in $0.02 \mathrm{M}$ sodium phosphate buffer containing $0.006 \mathrm{M} \mathrm{NaCl}, \mathrm{pH}$ 6.9. A $100 \mu \mathrm{L}$ aliquot of each sample (assay concentrations of 1.1-2.3 $\mathrm{mg} / \mathrm{mL})$ and $100 \mu \mathrm{L}$ of $\alpha$-amylase enzyme solution $(1 \mathrm{mg} / \mathrm{mL})$ were added to test tubes and allowed to incubate at $37^{\circ} \mathrm{C}$ for $10 \mathrm{~min}$. A sample blank was prepared with the enzyme omitted. After incubation, $100 \mu \mathrm{L}$ of $1 \%$ (w/v) starch solution was added to test tubes and the reaction mixture incubated at $37^{\circ} \mathrm{C}$ for $10 \mathrm{~min}$. The reaction was terminated by adding $200 \mu \mathrm{L}$ of $3,5-$ dinitro-salicylic acid (DNS) color reagent (96 mM DNSA, $2 \mathrm{M}$ sodium potassium tartrate tetrahydrate and $2 \mathrm{M} \mathrm{NaOH}$ ) followed by incubation in a boiling water bath at $100^{\circ} \mathrm{C}$ for $5 \mathrm{~min}$. The reaction mixture was allowed to cool to room temperature, after which $3 \mathrm{~mL}$ of MilliQ water was added. A $200 \mu \mathrm{L}$ aliquot of the reaction mixture was then transferred to a 96-well microplate and the absorbance read at $540 \mathrm{~nm}$ using a Synergy ${ }^{\mathrm{TM}} \mathrm{H} 4$ microplate reader $\left(\right.$ Biotek $^{\mathrm{TM}}$, Vermont, USA) set at $37^{\circ} \mathrm{C}$. Acarbose $(\alpha-$ amylase inhibitory drug) at $10 \mu \mathrm{g} / \mathrm{mL}$ was used as the positive control. Percentage inhibitions of all samples were calculated using the equation:

$$
\operatorname{Inhibition}(\%)=[\mathrm{Ac}-(\mathrm{As}-\mathrm{Asb}) / \mathrm{Ac}] \times 100
$$

Ac $=$ Absorbance of the negative control (uninhibited reaction), As $=$ Absorbance of the sample (inhibited reaction), and Asb = Absorbance of the sample blank (enzyme omitted).

\section{Pancreatic Lipase Inhibition}

PL inhibitory activity of the extracts was determined according to protocols described in previous methods $(38,39)$ with slight modifications. PL activity was measured using the release of 4-methylumbelliferone (4-MU) from the substrate, which is 4methylumbelliferyl oleate (4-MU oleate). A $25 \mu \mathrm{L}$ aliquot of samples (assay activity of $0.5-2.5 \mathrm{mg} / \mathrm{mL}$ ) dissolved in Tris-buffer (13 mM Tris- $\mathrm{HCl}, 150 \mathrm{mM} \mathrm{NaCl}$ and $1.3 \mathrm{mM} \mathrm{CaCl}_{2}, \mathrm{pH}=8$ ) and $225 \mu \mathrm{L}$ of a $0.5 \mathrm{mM} 4-\mathrm{MU}$ oleate solution were mixed in a 96-well microplate and incubated for $15 \mathrm{~min}$ at $37^{\circ} \mathrm{C}$. An enzyme blank was prepared with the substrate omitted. After incubation, $25 \mu \mathrm{L}$ of PL solution (assay concentration $=3.125 \mathrm{U} / \mathrm{mL}$ ) was added to start the enzyme reaction and then incubated at $37^{\circ} \mathrm{C}$ for $1 \mathrm{~h}$. After incubation, the amount of 4-methylumbelliferone released by the lipase was measured with a fluorimeter at an excitation wavelength of $340 \mathrm{~nm}$ and emission wavelength of $450 \mathrm{~nm}$. Orlistat (PL inhibitory drug at $0.25 \mathrm{mg} / \mathrm{mL}$ ) served as a positive control and was analyzed using same protocol. The PL inhibitory activity (\%) was calculated using the equation:

$$
\text { Inhibition }(\%)=[(\mathrm{Ac}-\mathrm{Aeb})-\mathrm{As}] /(\mathrm{Ac}-\mathrm{Aeb}) \times 100
$$

Ac $=$ Absorbance of the negative control (uninhibited reaction), As = Absorbance of the sample (inhibited reaction) and Aeb $=$ Absorbance of the enzyme blank (substrate omitted). The concentration of extract that reduced enzyme activity by $50 \%$ $\left(\mathrm{IC}_{50}\right)$ was obtained by non-linear regression analysis of a plot of PL inhibition (\%) vs. the sample concentrations using GraphPad Prism version 9.0 (GraphPad Software, San Diego, CA, USA).

\section{Intrinsic Fluorescence Emission}

The method described by $\mathrm{Li}$ and Aluko (40) was used to record intrinsic fluorescence spectra on the Jasco FP-6300 spectrofluorometer (JASCO, Tokyo, Japan) at $25^{\circ} \mathrm{C}$ with a $1 \mathrm{~cm}$ path length cuvette. Sample (leaf extracts) stock solutions (10 $\mathrm{mg} / \mathrm{mL}$ ) and enzymes (PL or $\alpha$-amylase) were prepared in $13 \mathrm{mM}$ Tris- $\mathrm{HCl}$ buffer containing $150 \mathrm{mM} \mathrm{NaCl}$ and $1.3 \mathrm{mM} \mathrm{CaCl}_{2}, \mathrm{pH}$ 8 for $\mathrm{PL}$ or $20 \mathrm{mM}$ sodium phosphate, containing $6 \mathrm{mM} \mathrm{NaCl}$, pH 6.9 for amylase. The enzyme and sample solutions were then mixed to obtain assay concentrations of $1 \mathrm{mg} / \mathrm{mL}$ and $6.25-$ $50 \mu \mathrm{g} / \mathrm{mL}$, respectively, which were then used for fluorescence emission measurement. The fluorescence spectra were recorded at an excitation wavelength of $275 \mathrm{~nm}$ and emission wavelength range of 280-450 nm. Buffer emission spectrum was subtracted from those of the respective samples to obtain reported spectrum of each enzyme/extract mixture.

\section{Measurement of Circular Dichroism Spectra}

The CD spectra of enzyme/leaf extract mixtures ( $\alpha$-amylase and PL) complexes were measured at $25^{\circ} \mathrm{C}$ in a $\mathrm{J}-810$ spectropolarimeter (JASCO, Tokyo, Japan) using the spectral range of 190-240 $\mathrm{nm}$ (far-UV) for secondary structure determinations and $250-320 \mathrm{~nm}$ (near-UV) for tertiary structure (41). Stock solutions of extract and that of the enzymes (PL and $\alpha$ - amylase) were prepared as described above for intrinsic fluorescence. The extract and enzyme solutions were mixed to give assay concentrations of $1-3 \mathrm{mg} / \mathrm{mL}$ and $1 \mathrm{mg} / \mathrm{mL}$, respectively. The far-UV and near-UV spectra were acquired using 0.05 and $0.1 \mathrm{~cm}$ cuvette path lengths, respectively. The 
reported enzyme spectra were obtained after subtraction of the respective buffer spectrum.

\section{Statistical Analysis}

Triplicate determinations were used to obtain mean values and standard deviations. For statistical analysis, one-way analysis of variance (ANOVA) was carried out. Significant differences $(p<$ 0.05 ) between mean values were determined using the Duncan's multiple-range test. Statistical analyses were performed with the IBM SPSS Statistical package (version 24).

\section{RESULTS AND DISCUSSION}

\section{$\alpha$-Amylase Inhibition}

$\alpha$-amylase is one of the main enzymes involved in the breakdown of dietary starch, giving rise to oligosaccharides that can be further broken down to absorbable monosaccharides in the brush border of the intestine. Inhibition of this enzyme is therefore considered an active strategy for managing diabetes. The inhibitory activity of the polyphenolic extracts increased with increasing concentration, indicating a dose-dependent effect (Figures 1A-C). This corresponds with the report of Sachan et al. (4), which also reported dose-dependent inhibitory activities for the organic extracts of the medicinal plants Pluchea lanceolata, Alhagi pseudalhagi, and Caesalpinia bonduc. Among the three vegetable extracts tested, TO-40-T2 $(100.00 \%$ at $1.8 \mathrm{mg} / \mathrm{mL})$ had the highest inhibition followed by SM-20-T1 (75.74 \%) and $\mathrm{AV}-20-\mathrm{T} 1(68.45 \%)$ at $2.3 \mathrm{mg} / \mathrm{mL}$, respectively. However, there was no direct relationship between fertilizer dose and inhibition of $\alpha$-amylase activity. The inhibitory activity of the extracts was lower than that of the standard acarbose $(86.64 \%$ at $10 \mu \mathrm{g} / \mathrm{mL})$. When comparing the three vegetable extracts, it was observed that all the TO extracts showed highest inhibitory activity at $1.8 \mathrm{mg} / \mathrm{mL}$ assay concentration after which the activity decreased. This indicate that at concentrations $>1.8 \mathrm{mg} / \mathrm{mL}$, there may have been antagonistic interactions between the extract constituents, which led to reduced interactions with the enzyme. This antagonistic effect could be due to increased polyphenolpolyphenol interactions or binding of a compound occupies a space on the enzyme surface or active site, which prevents attachment of other compounds. The results obtained for SM extracts also show weaker inhibitory effects when compared to Solanum melongena (40.11\%) and Solanum macrocarpon $(42.66 \%)$ at $80 \mu \mathrm{g} / \mathrm{mL}$ as previously reported (34). Differences in activities may be due to variations in cultivar and agronomic practices as well as the extraction media (aqueous vs. organic), which could affect the type and ratio of polyphenolic compounds present in the extracts. Our previous work has showed that the main polyphenolic compounds in the AV, SM, and TO vegetable leaf extracts are caffeic acid, rutin, and myricetin $(35,36)$. However, the work of Nwanna (34) with SM extracts did not indicate the dominant polyphenols.

The effects of fertilizer dose, time of fertilizer application and vegetable variety differences on the inhibitory activity of the extracts were analyzed using three-way ANOVA (Table 1). The results show that there are significant differences $(p<$ 0.05 ) among the fertilizer dose treatments. The leaf extract from
A

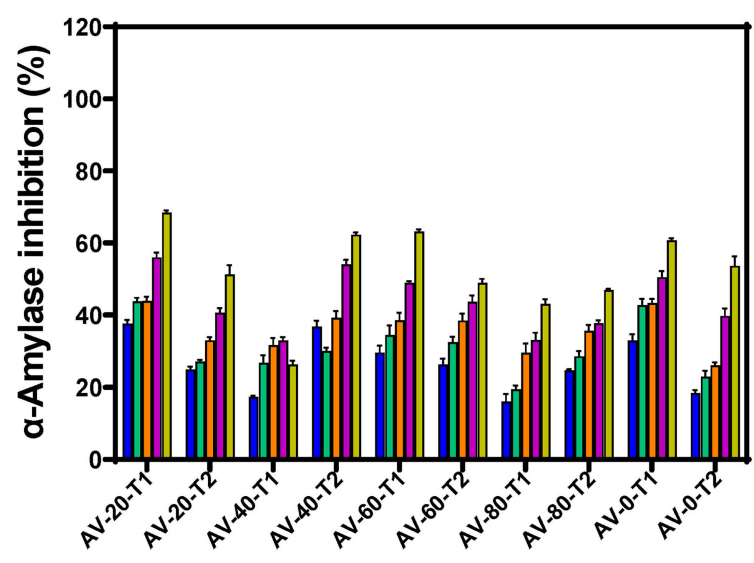

B

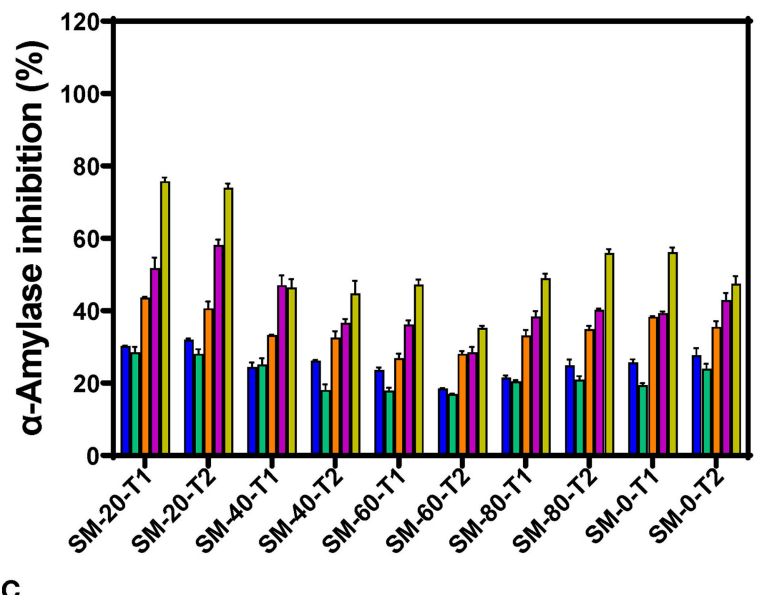

C

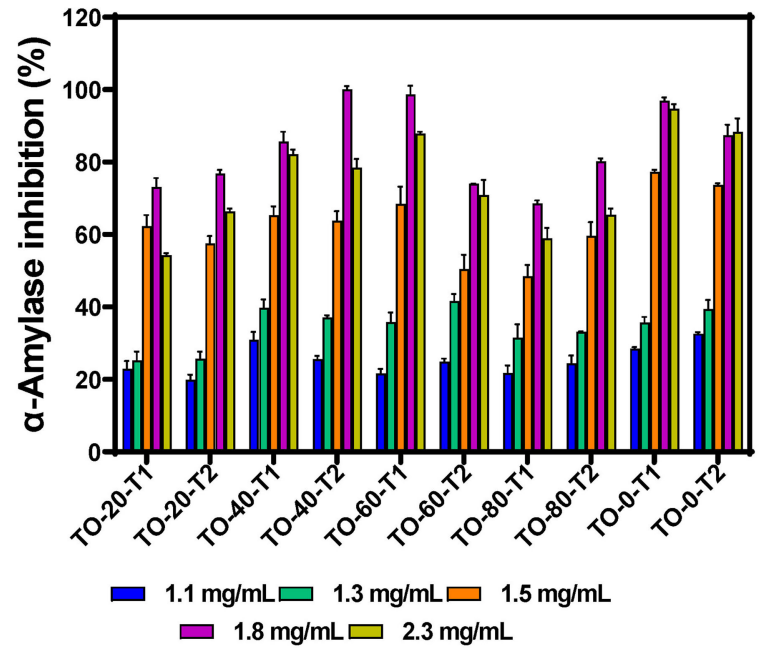

FIGURE 1 | $\alpha$-amylase inhibition by aqueous extracts from the dried leaves of (A) Amaranthus viridis (AV), (B) Solanum macrocarpon (SM) and (C) Telfairia occidentalis (TO). Plants were produced with different urea fertilizer doses ( 0 , 20, 40, 60, and $80 \mathrm{~kg} \mathrm{~N} / \mathrm{ha}$ ), which were applied at (T1) or after (T2) planting. Each bar is the mean of 3 determinations while the error bar represents standard deviation. 
TABLE 1 | Results from 3-way ANOVA and Duncan's test of the effects of vegetable variety, (W); fertilizer dose, (FD); fertilizer application time, (FAT): T1 at planting, T2 after planting; Telfairia occidentalis, TO; Solanum marcrocarpon, SM; Amaranthus viridis, AV; (OT-80T as fertilizer dosing treatments) on $\alpha$-amylase inhibitory activity of vegetable leaf aqueous extracts.

\begin{tabular}{|c|c|c|c|c|c|c|c|c|c|c|}
\hline \multirow[t]{2}{*}{ Parameter } & \multicolumn{3}{|c|}{ Mean intensity for VV } & \multicolumn{4}{|c|}{ Mean intensity for FD } & \multirow[b]{2}{*}{$80 \mathrm{~T}$} & \multicolumn{2}{|c|}{ Mean intensity for FAT } \\
\hline & SM & AV & TO & OT & 20T & $40 \mathrm{~T}$ & $60 \mathrm{~T}$ & & T1 & T2 \\
\hline $\begin{array}{l}\text { Inhibition of } \alpha \text {-amylase } \\
\text { activity }(\%)^{1}\end{array}$ & $\begin{array}{l}53.19^{a} \\
(0.360)\end{array}$ & $\begin{array}{l}52.59^{a} \\
(0.360)\end{array}$ & $\begin{array}{l}74.92^{b} \\
(0.360)\end{array}$ & $\begin{array}{l}66.85^{e} \\
(0.464)\end{array}$ & $\begin{array}{l}64.99^{d} \\
(0.464)\end{array}$ & $\begin{array}{l}56.44^{b} \\
(0.464)\end{array}$ & $\begin{array}{l}58.91^{c} \\
(0.464)\end{array}$ & $\begin{array}{l}53.99^{a} \\
(0.464)\end{array}$ & $\begin{array}{l}61.06^{\mathrm{a}} \\
(0.294)\end{array}$ & $\begin{array}{l}59.42^{b} \\
(0.294)\end{array}$ \\
\hline
\end{tabular}

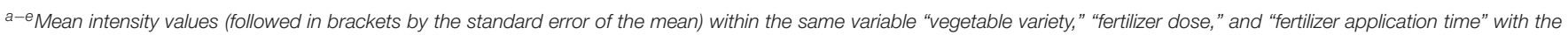
same letter within the same row (parameter) are not significantly different $(p<0.05) .{ }^{1} 2.3 \mathrm{mg} / \mathrm{mL}$ extract concentration.

urea fertilizer dose of $80 \mathrm{~kg} \mathrm{~N} / \mathrm{ha}$ (53.99\%) had the lowest $\alpha$ amylase inhibition while that of the control treatment $(0 \mathrm{~kg}$ $\mathrm{N} / \mathrm{ha}$ - with only organic fertilizer) had the highest inhibition (66.85\%). The rate of $\alpha$-amylase inhibition decreased as the rate of urea fertilizer dose increased indicating a negative effect, which could not be explained by the differences in content of polyphenolic compounds that we previously reported $(35,36)$. Nitrogen is an important nutrient required for plant growth and metabolism of cellular compounds such as proteins, nucleic acids, ATP, chlorophyll, pigments, and for production of secondary metabolites (42). A study conducted using green and red lettuce indicate that low nitrogen availability increased the concentration of phenolic compounds (43) while in basil leaves (44-46), Sesamum indicum (47) and Hypericum pruinatum (48), higher nitrogen availability led to a decrease in rosmarinic acid, the main phenolic compounds, which may explain the results obtained in this study. The reduction in $\alpha$-amylase inhibition could also be explained by the study done by Olarewaju et al. (30), which observed that increase in fertilizer dose led to a decrease in polyphenol content of leaf extracts of AV, SM, and TO. Therefore, the results suggest that the synthesis of polyphenolic compounds is not necessarily supported by higher concentration of nitrogen fertilizer. Thus, precise or optimized targeted use of nitrogen fertilizer could be an effective strategy for enhancing bioactive properties of plants. The time of urea fertilizer application also significantly $(p<0.05)$ affected the rate of $\alpha$-amylase inhibition by the leaf extracts because application at the time of planting led to significantly $(p<0.05)$ higher $(61.01 \%)$ value than when applied two weeks after planting (59.42\%). Among the three vegetable extracts, TO leaf extracts had significantly $(p<0.05)$ higher inhibition of $\alpha$-amylase activity when compared to SM and AV extracts. The stronger inhibitory effect of TO extracts may be due to the higher contents of caffeic acid as previously reported $(35,36)$. The results are consistent with findings that plants contain some chemical substances which are potential inhibitors of $\alpha$-amylase and due to this they can be used as therapeutic agents or as functional foods in the management of diseases associated with carbohydrate uptake (49).

\section{Pancreatic Lipase Inhibition}

The $\mathrm{IC}_{50}$ values of samples, which reflect the concentration of the extracts at which $50 \%$ of enzyme activity is inhibited (compared to the uninhibited reaction) are presented in Figures 2A-C. Throughout the investigation, the aqueous extracts of TO show the highest PL inhibitory effects but TO-0-T2, AV-0-T1and SM0 -T2 (zero nitrogen fertilizer) had the highest inhibitory activity with $\mathrm{IC}_{50}$ values of $1.000,1.006$, and $1.038 \mathrm{mg} / \mathrm{mL}$, respectively, when compared to the other TO, SM and AV samples. The results show very similar values for the TO samples (T1 and T2) while the SM and AV samples had more variations. The results indicate a negative effect of nitrogen fertilizer application on the PL-inhibitory activity of extracts. Therefore, application of urea fertilizer may not be compatible with producing AV, SM, and TO leaves that contain polyphenolic compounds with strong high enzyme-inhibitory potency. The PL inhibition efficacy obtained in this study is lower than those obtained for aqueous extracts of Vitis vinifera and Rhus coriaria with $\mathrm{IC}_{50}$ values of 14.14 and $19.95 \mu \mathrm{g} / \mathrm{mL}$, respectively (50). The variation in these results may be attributed to the type of method used in determining PL activity and the effect of different bioactive compounds present in the extracts. Other studies have identified natural products for their PL inhibition with profound inhibition effect on fat digestion. Some of these plants include Ononis natrix $\left(\mathrm{IC}_{50}\right.$ $167 \mu \mathrm{g} / \mathrm{mL}$ ), Fagonia arabica ( $\mathrm{IC}_{50} 204.1 \mu \mathrm{g} / \mathrm{mL}$ ), Origanum syriaca $\left(\mathrm{IC}_{50} 234 \mu \mathrm{g} / \mathrm{mL}\right.$ ), and Hypericum triquetrifolium ( $\mathrm{IC}_{50}$ $236.2 \mu \mathrm{g} / \mathrm{mL}$ ) (51). Teixeira et al. (52) also found that Passiflora nitida extract inhibited $\mathrm{PL}$ with an $\mathrm{IC}_{50}$ value of $21.2 \pm$ $0.8 \mu \mathrm{g} / \mathrm{mL}$. Although transferring in vitro experiment to in vivo experiment might not bring out the same outcome but with the high inhibition rate of the leaf extract of $\mathrm{AV}, \mathrm{SM}$, and $\mathrm{TO}$, conducting an in vivo study using this leaf extracts might pave way for a better understanding of their mechanism of action, possible side effect and their optimal dose. Establishing this will give rise to a more effective and safer strategy in the management or treatment of obesity.

The three-way ANOVA results (Table 2) revealed a significant difference in the inhibitory activity of the extracts of AV, SM, and TO. Extracts with fertilizer dose of $60 \mathrm{~kg} \mathrm{~N} / \mathrm{ha}$ had the lowest PL inhibitory activity while the control treatment $(0 \mathrm{~kg} \mathrm{~N} / \mathrm{ha})$ had the highest inhibitory effect among all the samples. This shows that extracts from the control treatment (no nitrogen fertilizer) are better inhibitors of PL when compared with extracts that contain both organic and urea fertilizers $(20,40$, and $60 \mathrm{~kg} \mathrm{~N} / \mathrm{ha})$. Among the three leaf extracts studied, TO have the best inhibitory effect when compared with the other two vegetables (SM and $\mathrm{AV})$. The time of fertilizer application significantly affected the rate at which the extracts inhibited PL activity. Leaf extracts from plants that received fertilizer treatment at the time of planting 
A

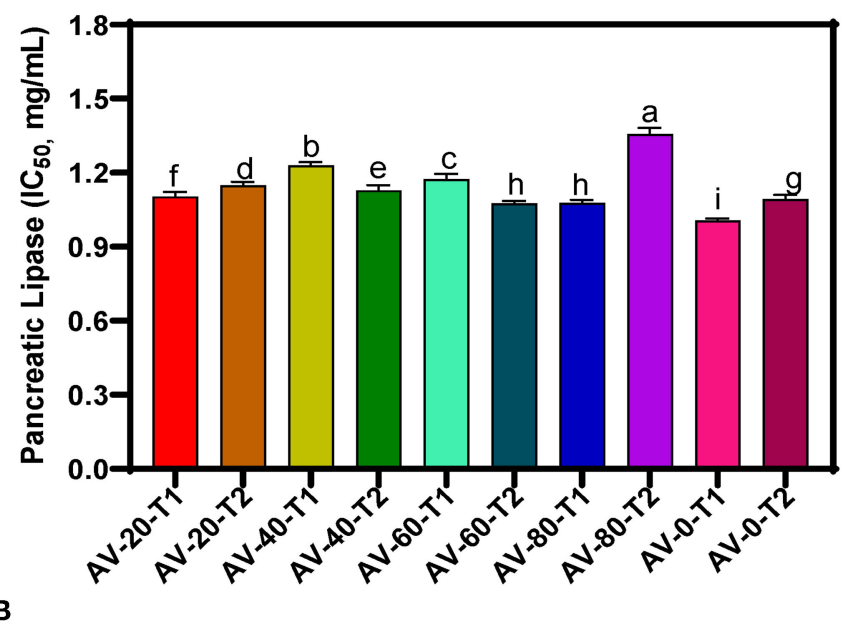

B
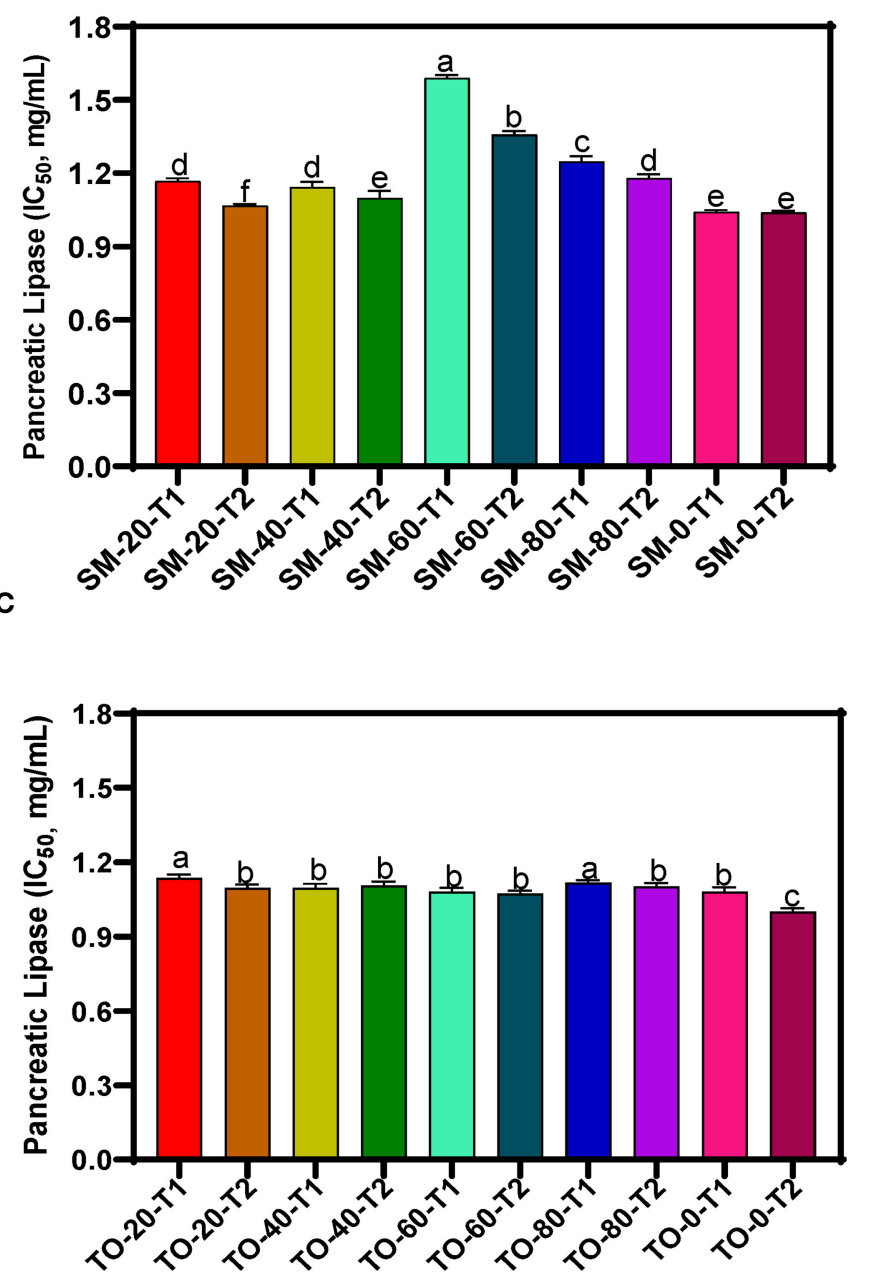

FIGURE 2 | Pancreatic lipase inhibition of aqueous extracts from the dried leaves of (A) Amaranthus viridis leaves (AV), (B) Solanum macrocarpon (SM) and (C) Telfairia occidentalis (TO). Plants were produced with different urea fertilizer doses (0, 20, 40, 60, and $80 \mathrm{~kg} \mathrm{~N} / \mathrm{ha})$, which were applied at (T1) or after (T2) planting. Each bar is the mean of 3 determinations while the error bar represents standard deviation. Bars with different letters $(a-g)$ have mean values that are significantly $(p<$ 0.05) different. 
TABLE 2 | Results from 3-way ANOVA and Duncan's test of the effects of vegetable variety, (W); fertilizer dose, (FD); fertilizer application time, (FAT): T1 at planting, T2 after planting; Telfairia occidentalis, (TO); Solanum marcrocarpon, (SM); Amaranthus viridis, (AV); (OT-80T as fertilizer dosing treatments) on pancreatic lipase inhibitory activity of vegetable extracts.

\begin{tabular}{|c|c|c|c|c|c|c|c|c|c|c|}
\hline \multirow[t]{2}{*}{ Parameter } & \multicolumn{3}{|c|}{ Mean intensity for VV } & \multicolumn{5}{|c|}{ Mean intensity for FD } & \multicolumn{2}{|c|}{ Mean intensity for FAT } \\
\hline & SM & AV & TO & OT & $20 \mathrm{~T}$ & $40 \mathrm{~T}$ & $60 \mathrm{~T}$ & $80 \mathrm{~T}$ & T1 & T2 \\
\hline Inhibition of pancreatic & $76.125^{b}$ & $74.57^{\mathrm{a}}$ & $77.71^{\mathrm{c}}$ & $82.14^{d}$ & $74.51^{b}$ & $76.77^{\mathrm{c}}$ & $71.28^{\mathrm{a}}$ & $75.97^{b}$ & $76.59^{\mathrm{a}}$ & $75.92^{b}$ \\
\hline lipase activity ${ }^{1}$ & $(0.275)$ & $(0.275)$ & $(0.275)$ & $(0.355)$ & $(0.355)$ & $(0.355)$ & $(0.355)$ & $(0.355)$ & $(0.225)$ & $(0.225)$ \\
\hline
\end{tabular}

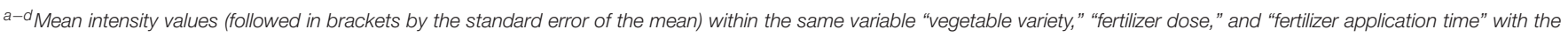
same letter within the same row (parameter) are not significantly different $(p<0.05) .{ }^{1} 2.5 \mathrm{mg} / \mathrm{mL}$ extract concentration.

(T1) were better inhibitors of PL than those from plants fertilized two weeks after planting (T2). The reason is not clear but could be that early fertilizer application ensured faster synthesis and accumulation of inhibitory polyphenolic compounds than the late treatment.

\section{Intrinsic Fluorescence Emission $\alpha$-Amylase}

The effects of leaf extracts on $\alpha$-amylase conformational changes were evaluated by intrinsic fluorescence intensity measurements using samples with same nitrogen fertilizer treatment $(20 \mathrm{~kg}$ $\mathrm{N} /$ ha). Changes in the emission spectra of tryptophan are common in response to protein conformational transitions, subunit association, substrate binding, or denaturation (53). The results show varied outcomes but mostly increases in the fluorescent intensity (FI) at higher concentration of leaf extracts (Figures 3A-F). Decreases in the FI represent the unfolding of the protein structure and exposure of tryptophan residues to a more polar environment while increases suggest shift to nonpolar environments $(24,26)$. The results suggest that at some concentrations, addition of the extracts led to a loose $\alpha$-amylase protein conformation with greater exposure to the hydrophilic environment, hence FI quenching. However, for all the three leaf varieties at the highest concentration of $50 \mu \mathrm{g} / \mathrm{mL}$, the $\alpha$-amylase aromatic amino acids may have interacted with the polyphenolic compounds in the extract, which reduced exposure to the hydrophilic environment, hence increased FI. $\alpha$-amylase alone had wavelength of maximum FI $(\lambda \max )$ at $344 \mathrm{~nm}$, which was red shifted after addition of the extracts. The red-shift indicates changes to the tryptophan microenvironment with greater exposure to hydrophilic residues upon binding with polyphenols in the extracts (24). At 6.25 and $12.5 \mu \mathrm{g} / \mathrm{mL}$, a shift from 344 to $346 \mathrm{~nm}$ occurred for all the extracts except for AV-20-T2, which instead shifted to $348 \mathrm{~nm}$. However, at 25 and $50 \mu \mathrm{g} / \mathrm{mL}$, there was increased red shift to $350 \mathrm{~nm}$ for all the extracts. This suggests that the tryptophan residues inside the protein molecules were more exposed to the protein surfaces thus making the tryptophan environment more polar (54). Results showing changes in FI and $\lambda \max$ indicate that the $\alpha$-amylase inhibitory activity of the AV, SM, and TO leaf extracts as shown in Figure 1 is due to ability of the extracts to change the enzyme protein structure from a conformation that facilitated substrate catalysis into those not favorable for optimum enzyme activity. Interaction of polyphenols with enzymes could bring about changes in the emission spectra of the enzymes due to polyphenol binding. The reaction of polyphenol compounds such as epigallocatechin$\mathrm{G}$, epigallocatechin, epicatechin-G, naringenin, kaempferol-glu, caffeic acid, rosmarinic acid, and p-coumaric acid with bovine serum albumin (BSA) shows that, these polyphenols can quench the intrinsic fluorescence of BSA. Titration of epigallocatechinG, epigallocatechin, epicatechin-G with BSA showed a higher shift in the emission spectra indicating a more polar environment for tryptophan while the emission spectra of BSA was not significantly affected by other polyphenols (55). This suggest that the result obtained in our study could be attributed to activity of the polyphenol compounds (rutin, caffeic acid, and myricetin) present in the $\mathrm{AV}, \mathrm{SM}$, and $\mathrm{TO}$ leaf extracts. Therefore, the changes observed in the FI at different concentrations of the $\mathrm{AV}$, SM, and TO leaf extract may be due to the direct quenching or as a result of enzyme conformational changes induced by the reaction of polyphenol compounds with $\alpha$-amylase protein (55). It is also possible that hydrogen bonding occurred between the polyphenols of the $\mathrm{AV}, \mathrm{SM}$, and TO leaf extracts and $\alpha$-amylase thus altering the microenvironment of the intrinsic chromophore groups of the enzyme $(56,57)$.

\section{Pancreatic Lipase}

FI was also used to evaluate PL structural changes as a result of addition of various leaf extract concentrations. The results show that increases in the concentration of $\mathrm{AV}, \mathrm{SM}$, and TO leaf extracts led to decreased FI, which indicate conformational changes that exposed the aromatic amino acids to a more polar environment (Figures 4A-F). PL exhibited a single fluorescence emission peak at $346 \mathrm{~nm}$, which is due to the presence of tryptophan amino acid residue. Therefore, decreases in FI suggest unfolding of the PL protein molecule, which led to increased tryptophan interactions with the hydrophilic environment. Addition of SM-40-T1 and TO-40-T1 resulted in a slight blue shift of $\lambda \max$ to $344 \mathrm{~nm}$ and SM-40-T2 exhibited a red shift to $348 \mathrm{~nm}$ at $6.25 \mu \mathrm{g} / \mathrm{mL}$. A similar result was reported for the interaction between caffeic acid and PL (58). The blue shift obtained upon addition of the AV, $\mathrm{SM}$, and TO leaf extracts indicates changes that moved the tryptophan into a more hydrophobic environment $(24,59)$. This suggests that there was structural reorganization that led to unfolding of enzyme molecule accompanied by changes in the microenvironment of tryptophan and tyrosine residues in the protein $(54,59)$. The lower FI values observed for the enzyme 
A

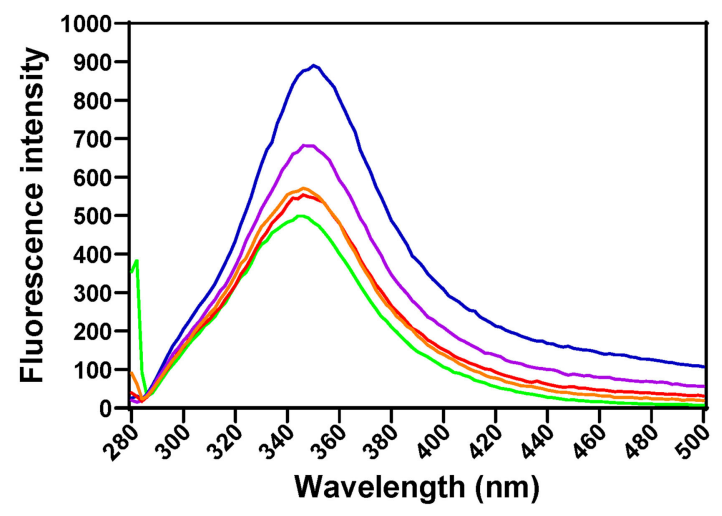

$-0 \mu \mathrm{g} / \mathrm{mL}-6.75 \mu \mathrm{g} / \mathrm{mL}-12.5 \mu \mathrm{g} / \mathrm{mL}$

C

$-25 \mu \mathrm{g} / \mathrm{mL} \quad-50 \mu \mathrm{g} / \mathrm{mL}$

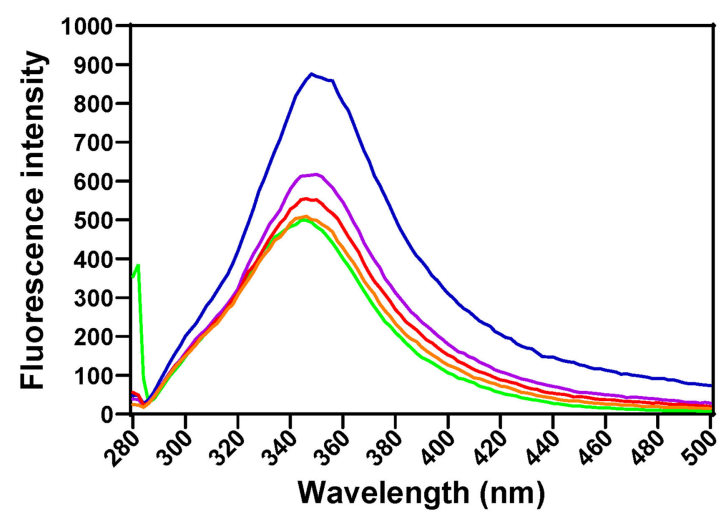

$-0 \mu \mathrm{g} / \mathrm{mL}-6.25 \mu \mathrm{g} / \mathrm{mL}-12.5 \mu \mathrm{g} / \mathrm{mL}$

E

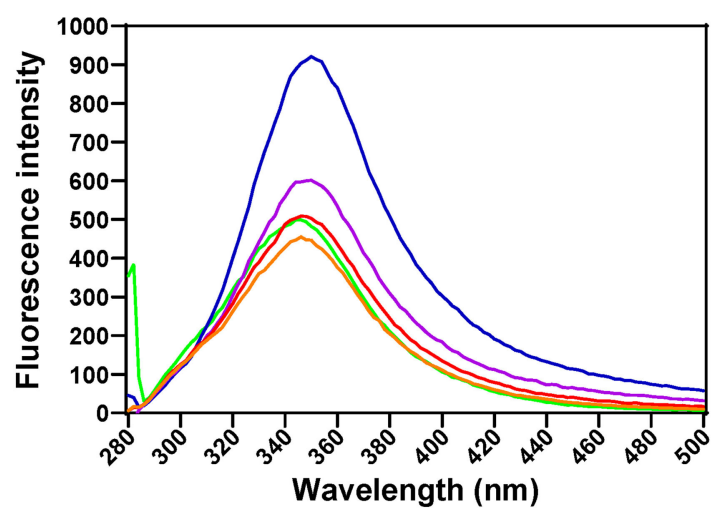

$-0 \mu \mathrm{g} / \mathrm{mL} \quad-6.25 \mu \mathrm{g} / \mathrm{mL} \quad-12.5 \mu \mathrm{g} / \mathrm{mL}$

$-25 \mu \mathrm{g} / \mathrm{mL} \quad-50 \mu \mathrm{g} / \mathrm{mL}$
B

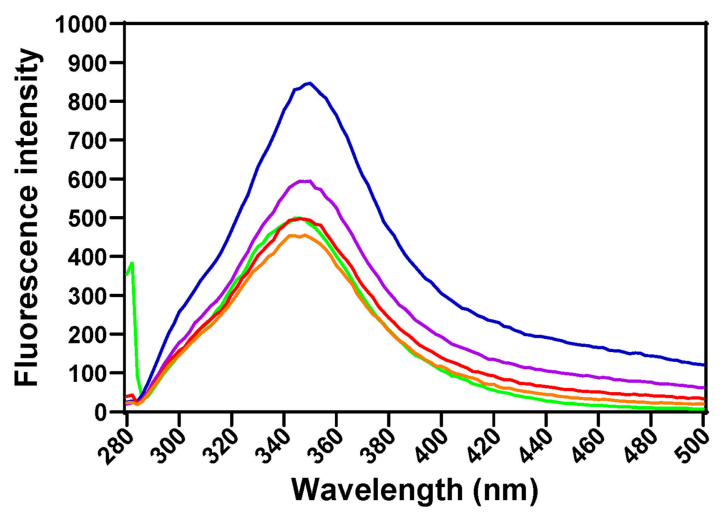

$-0 \mu \mathrm{g} / \mathrm{mL}-6.25 \mu \mathrm{g} / \mathrm{mL} \quad-12.5 \mu \mathrm{g} / \mathrm{mL}$

D
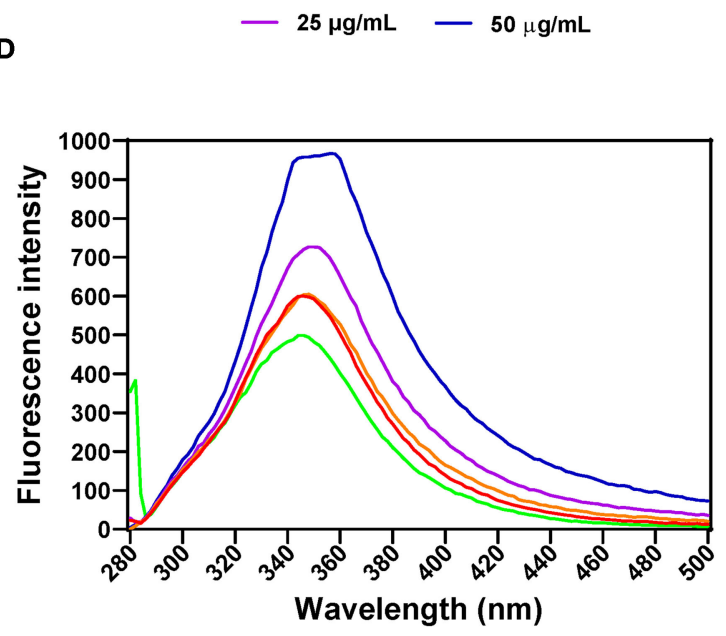

$-0 \mu \mathrm{g} / \mathrm{mL}-6.25 \mu \mathrm{g} / \mathrm{mL}-12.5 \mu \mathrm{g} / \mathrm{mL}$

$\mathbf{F}$

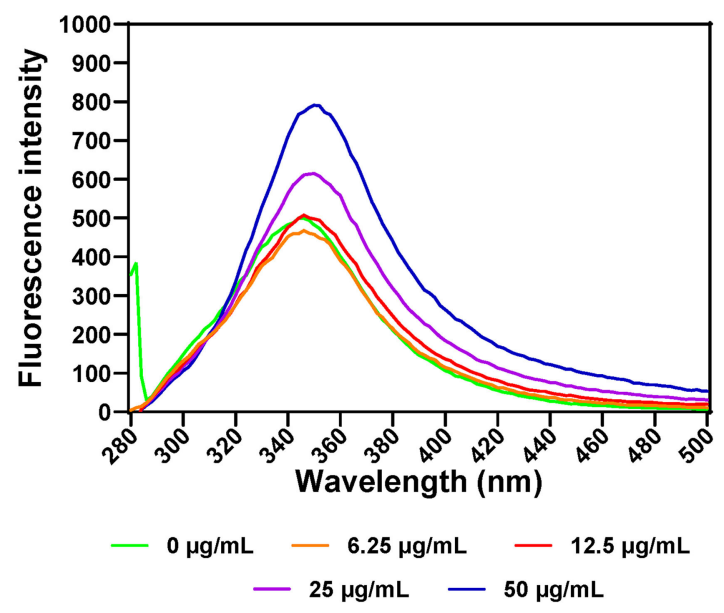

FIGURE 3 | Intrinsic fluorescence intensity of $\alpha$ - amylase in the presence of varied concentrations of leaf extracts from: (A) AV-20-T1, (B) AV-20-T2, (C) SM-20-T1, (D) SM-20-T2, (E) TO-20-T1, and (F) TO-20-T2. Plants were produced with nitrogen fertilizer (20 kg N/ha), which was applied at (T1) or after (T2) planting. 
A

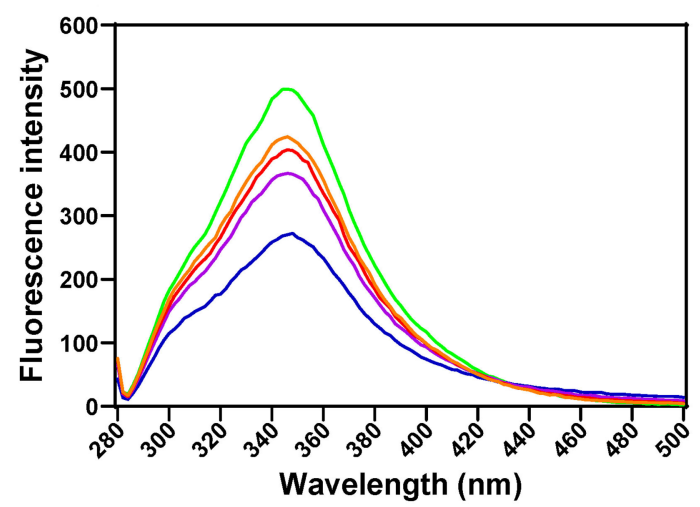

$-0 \mu \mathrm{g} / \mathrm{mL}-6.25 \mu \mathrm{g} / \mathrm{mL}-12.5 \mu \mathrm{g} / \mathrm{mL}$

- $25 \mu \mathrm{g} / \mathrm{mL} \quad-50 \mu \mathrm{g} / \mathrm{mL}$

C

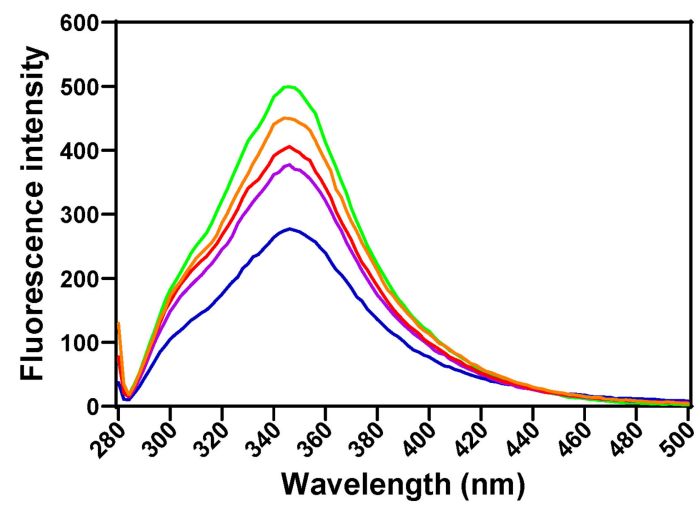

$-0 \mu \mathrm{g} / \mathrm{mL}-6.25 \mu \mathrm{g} / \mathrm{mL}-12.5 \mu \mathrm{g} / \mathrm{mL}$

E

$$
-25 \mu \mathrm{g} / \mathrm{mL} \quad-50 \mu \mathrm{g} / \mathrm{mL}
$$
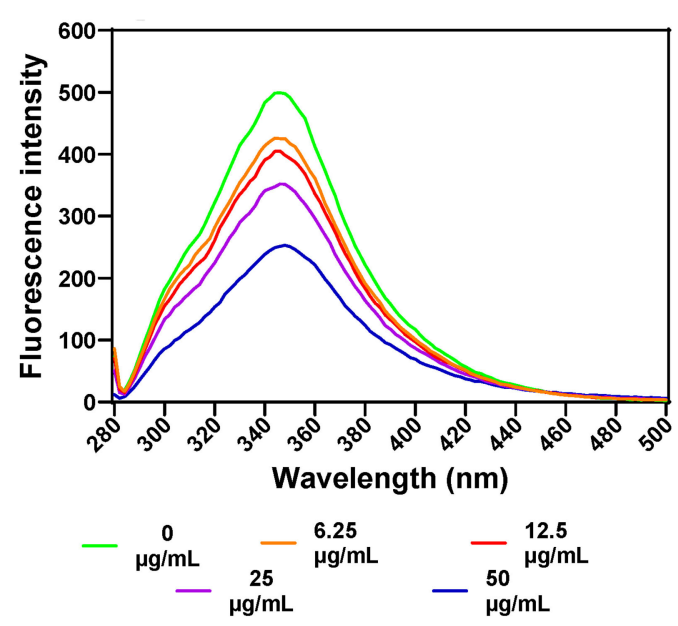

B

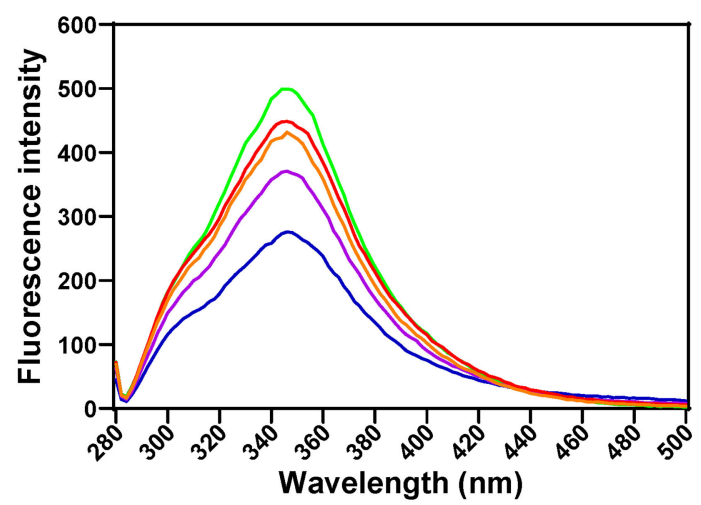

$-0 \mu \mathrm{g} / \mathrm{mL}-6.25 \mu \mathrm{g} / \mathrm{mL}-12.5 \mu \mathrm{g} / \mathrm{mL}$

- $25 \mathrm{ug} / \mathrm{mL} \quad-50 \mu \mathrm{g} / \mathrm{mL}$

D

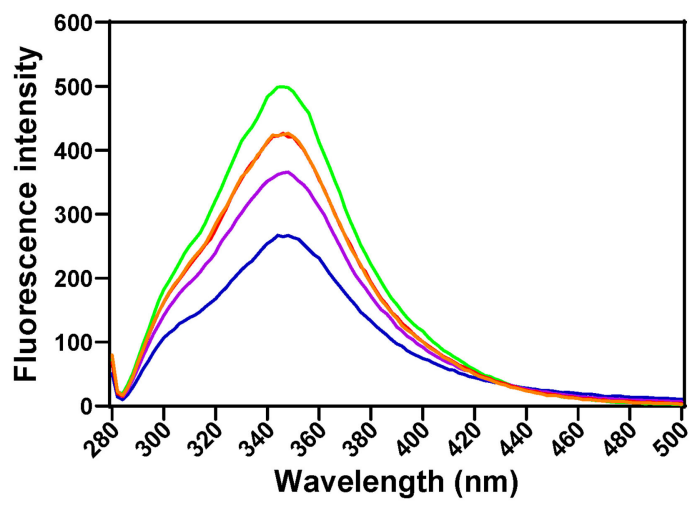

$-0 \mu \mathrm{g} / \mathrm{mL}-6.25 \mu \mathrm{g} / \mathrm{mL}-12.5 \mu \mathrm{g} / \mathrm{mL}$

- $25 \mu \mathrm{g} / \mathrm{mL}-50 \mu \mathrm{g} / \mathrm{mL}$

$\mathbf{F}$

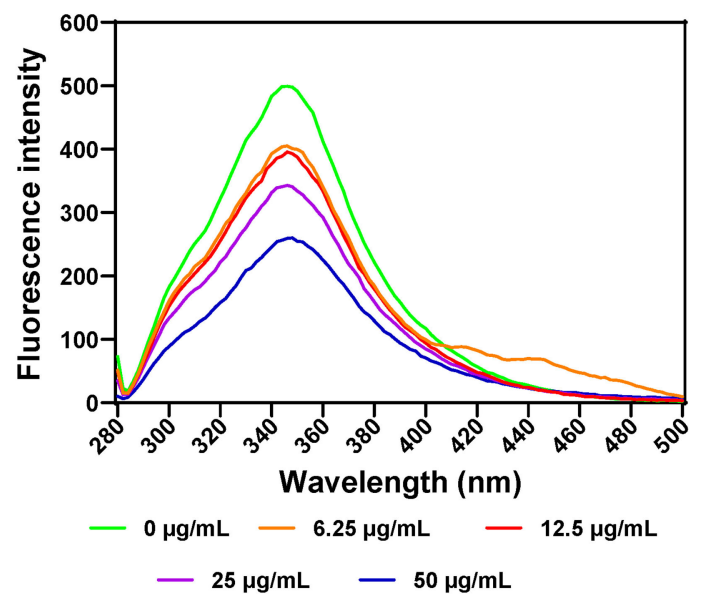

FIGURE 4 | Intrinsic fluorescent intensity of pancreatic lipase in the presence of varied concentrations of leaf extracts from: (A) AV-40-T1, (B) AV-40-T2, (C) 


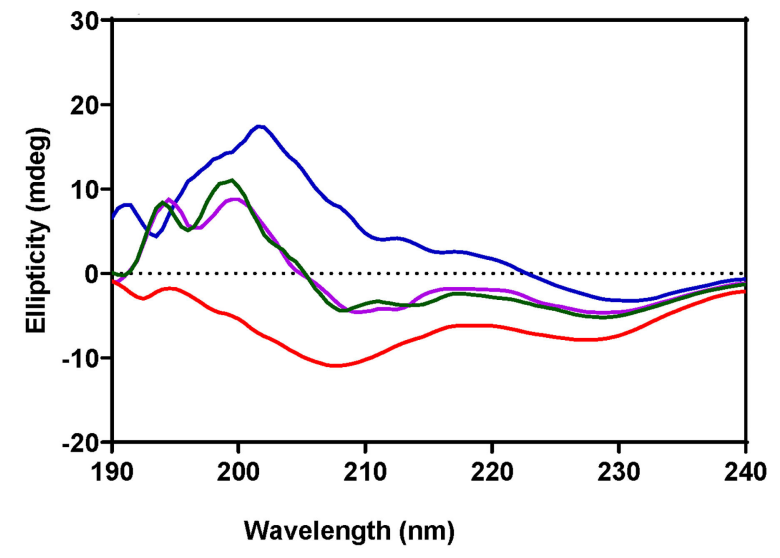

C

- $0 \mathrm{mg} / \mathrm{mL}-1 \mathrm{mg} / \mathrm{mL}-2 \mathrm{mg} / \mathrm{mL}-3 \mathrm{mg} / \mathrm{mL}$

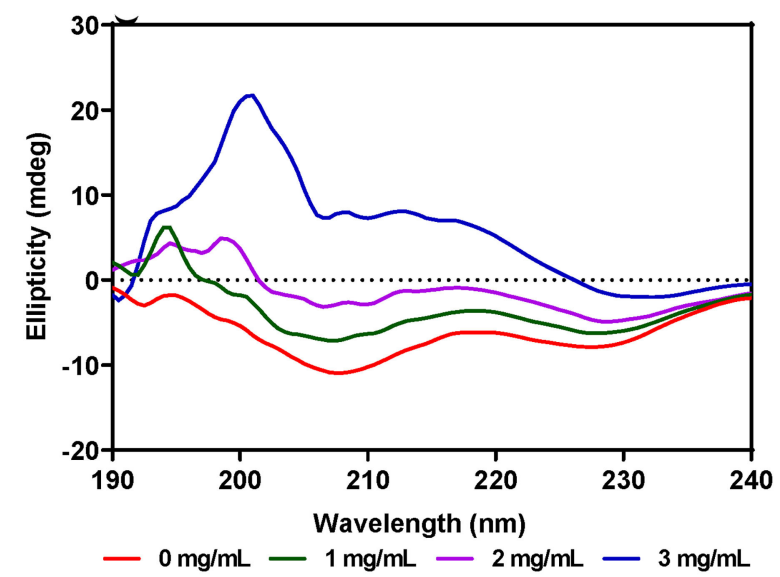

E

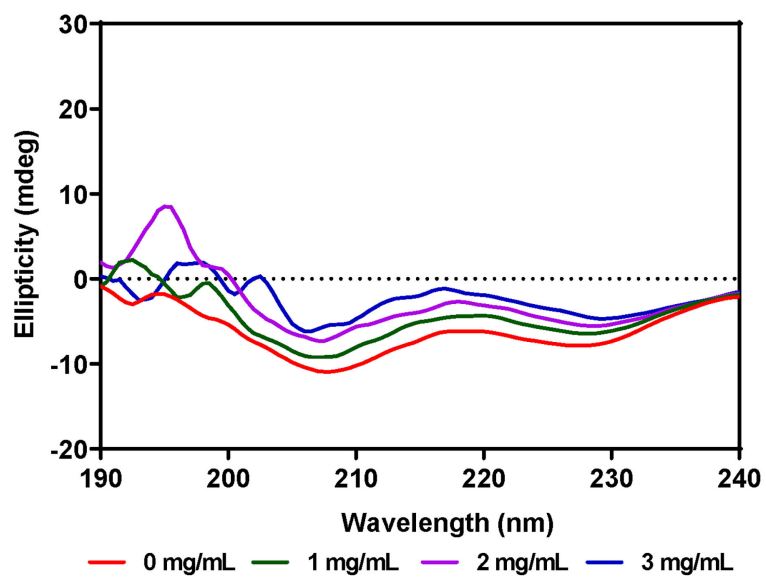

B

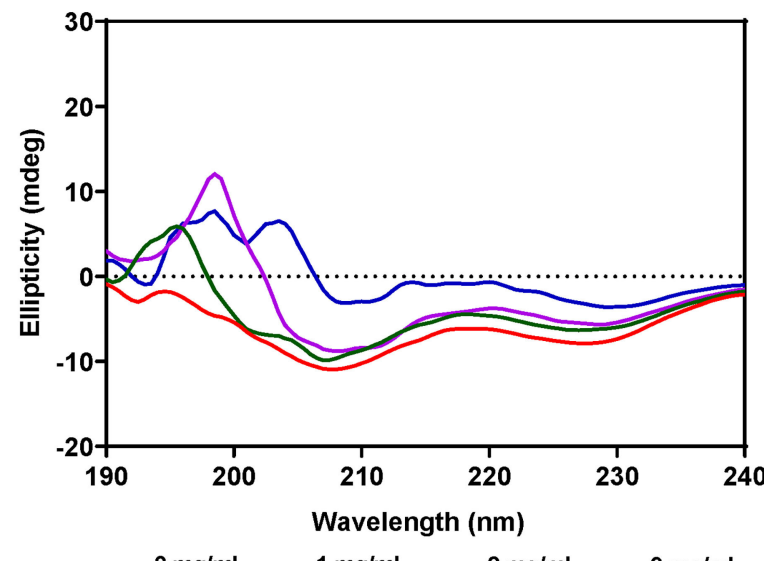

D

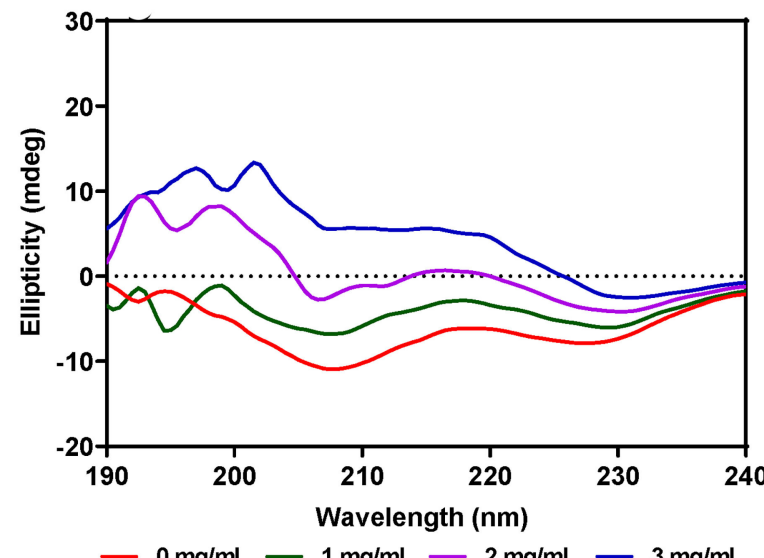

$\mathbf{F}$

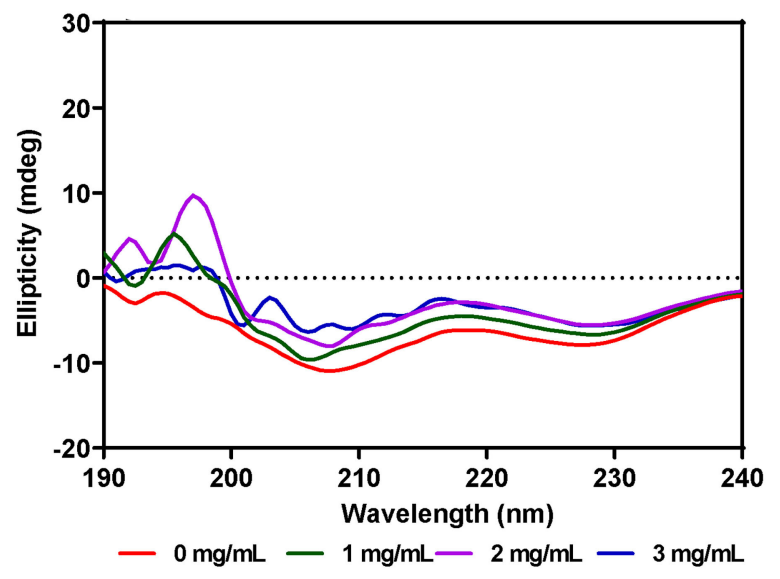

FIGURE 5 | Far-UV CD of $\alpha$-amylase in the presence of varied concentrations of leaf extracts from: (A) AV-20-T1, (B) AV-20-T2; (C) SM-20-T1, (D) SM-20-T2, (E) TO-20-T1, and (F) TO-20-T2. Plants were produced with nitrogen fertilizer (20 kg N/ha), which was applied at (T1) or after (T2) planting.

interaction with $50 \mu \mathrm{g} / \mathrm{mL}$ of $\mathrm{AV}, \mathrm{SM}$, and TO leaf extracts show that the tryptophan residues were most exposed to the polar environment, which represented the loosest conformation when compared to the lower concentrations $(58,60,61)$. A previous study reported similar results, which showed that the fluorescence intensity of pancreatic lipase decreased gradually 
at increased concentrations of quercetin, isoquercetin, and rutin with a slight blue shift from 354 to $351 \mathrm{~nm}$ (62). This suggests that flavonoids could expose tryptophan residue to a more hydrophobic environment and lead to attenuated fluorescence intensity of lipase. Gonçalves et al. (63) also reported a decrease in the FI of PL upon interactions with grape seed procyanidins but with no changes to the structure of PL. In another study, a different result was obtained, which reported an increased FI for the interactions of PL with galangin, kaempferol, quercetin, and myricetin (64). The results obtained in this study suggests that the fluorescence of PL was quenched by vegetable extracts as a results of protein structural unfolding, which is consistent with the observed reductions in PL activity.

\section{Far-UV Circular Dichroism Spectra $\alpha$-Amylase}

The secondary structure of $\alpha$-amylase in the presence of $\mathrm{AV}, \mathrm{SM}$, and TO leaf extracts was investigated using CD measurements between 190 and $240 \mathrm{~nm}$ at extract concentrations of 1, 2, and 3 $\mathrm{mg} / \mathrm{mL}$. The CD spectrum of $\alpha$-amylase alone indicate a typical signal of a protein containing both $\alpha$-helix and $\beta$-sheet as evident by the negative peaks at about 206-208 and 229-231 nm, and a positive peak in the $193-200 \mathrm{~nm}$ region (Figures 5A-F), which is similar to a previous report (65). The $\alpha$-amylase spectrum showed that the 206-208 and 229-231 nm peaks were reduced upon addition of the AV, SM, and TO leaf extracts, which suggest conformational changes that led to altered secondary structures. However, the intensity in the $193-200 \mathrm{~nm}$ region increased upon addition of the SM-20-T1, TO-20-T1, and TO-20-T2 extracts. The result is similar to data from a previous work which showed increased intensity of $193-200 \mathrm{~nm}$ region of $\alpha$-amylase CD spectra upon addition of a diosgenin from Dioscorea bulbifera (65). This shows that interaction of the leaf extracts with enzyme resulted in changes in the secondary structure conformation of $\alpha$ amylase. As observed for the intrinsic fluorescence data, addition of $50 \mu \mathrm{g} / \mathrm{mL}$ of leaf extracts resulted in the most change in ellipticity, especially for AV and SM samples. In contrast, changes to the $\alpha$-amylase $\mathrm{CD}$ spectra were minimal upon addition of TO extracts.

\section{Pancreatic Lipase}

Unlike $\alpha$-amylase, secondary structural changes to PL conformation in the presence of the $\mathrm{AV}, \mathrm{SM}$, and TO leaf extracts were modest with very minimal changes for AV-40-T1, AV-40-T2, SM-40-T1 and SM-40-T2 (Figures 6A-F). However, addition of the TO-40-T1 and TO-40-T2 extracts led to greater changes in ellipticity at 206-208 and 229-231 nm, which suggest ability to modulate enzyme secondary structure. The ability of TO extracts to produce greater modification of PL secondary structure is consistent with the observed stronger enzyme activity inhibition when compared to the AV and SM extracts. Results obtained in this work are consistent with previous reports that showed changes in $\alpha$-glucosidase (65), bovine serum albumin (66) and $\alpha$-lactalbumin (67) proteins secondary structure in the presence of polyphenolic compounds. For example, in the presence of tea epigallocatechin-3-gallate, there was a significant increase in the $190-200 \mathrm{~nm}$ peak of $\alpha$-lactalbumin when compared to the same protein alone.

\section{Near-UV CD Spectra $\alpha$-Amylase}

The tertiary structure of the $\alpha$-amylase in the presence of AV, SM, and TO leaf extracts was evaluated using near-UV CD. The CD spectra show that the structural conformation of the enzymes was significantly affected at different extract concentrations of $\mathrm{AV}, \mathrm{SM}$, and TO. The spectra for $\alpha$-amylase showed a prominent positive peak ellipticity at $269-270 \mathrm{~nm}$ and weak negative peak ellipticity at 296-298 nm (Figures 7A-F). Addition of 1 and $2 \mathrm{mg} / \mathrm{mL}$ AV-20-T1 did not change $\alpha$-amylase conformation but the $3 \mathrm{mg} / \mathrm{mL}$ produced an increased ellipticity peak in the 269-270 nm, which indicate structural changes that moved the aromatic groups away from the hydrophilic surface into more asymmetric environments when compared to the native enzyme. Addition of diogenin was also shown not to change the near$\mathrm{UV}$ spectra of $\alpha$-amylase (65). In contrast, addition of $1 \mathrm{mg} / \mathrm{mL}$ AV-20-T2 led to enzyme conformation changes that exposed the aromatic amino acids into less asymmetric environments as evident in the near-zero ellipticity. Increased concentrations $(2-3 \mathrm{mg} / \mathrm{mL})$ of AV-20-T2 produced no substantial changes in $\alpha$-amylase conformation. The SM-20-T1, SM-20-T2, TO-20$\mathrm{T} 1$, and TO-20-T2 extracts also produced changes in enzyme structure as shown by the increases or decreases in ellipticity peak at $269-270 \mathrm{~nm}$. Addition of varying levels of the AV, SM, and TO leaf extracts led to significant reductions in the $269-270 \mathrm{~nm}$ peak, suggesting a concentration-dependent modification of enzyme protein conformation. The observed larger losses of structural rigidity and asymmetric environments of $\alpha$-amylase in the presence of SM and TO extracts are consistent with the stronger enzyme inhibitory effects when compared to the AV extracts.

\section{Pancreatic Lipase}

The near-UV CD spectra for PL showed a positive peak ellipticity at 272-274 nm and negative peak ellipticity at 298-300 nm, which indicate that tyrosine and tryptophan are the main contributors to the observed structure (Figures 8A-F). Addition of AV-40-T1 led to disappearance of the 272-274 nm and 298-300 nm peaks, which indicate relocation of the aromatic amino acid residues to a more hydrophilic or less asymmetric environment. At 2-3 $\mathrm{mg} / \mathrm{mL}$, all the extracts (AV, SM, and TO) showed this type of behavior of significant reductions in the two peaks present in the native enzyme, which also suggest significant modifications to PL enzyme structure. The results are consistent with previous studies that have also shown interactions of polyphenols with enzymes can result in conformational changes to the tertiary structure of enzymes (68-71).

\section{CONCLUSIONS}

The aqueous extracts of AV, SM, and TO leaves had strong inhibitory activities against $\alpha$-amylase and PL. Fluorescence intensity analysis coupled with CD indicate that in the presence of leaf extracts, there were changes to enzyme structure 
A

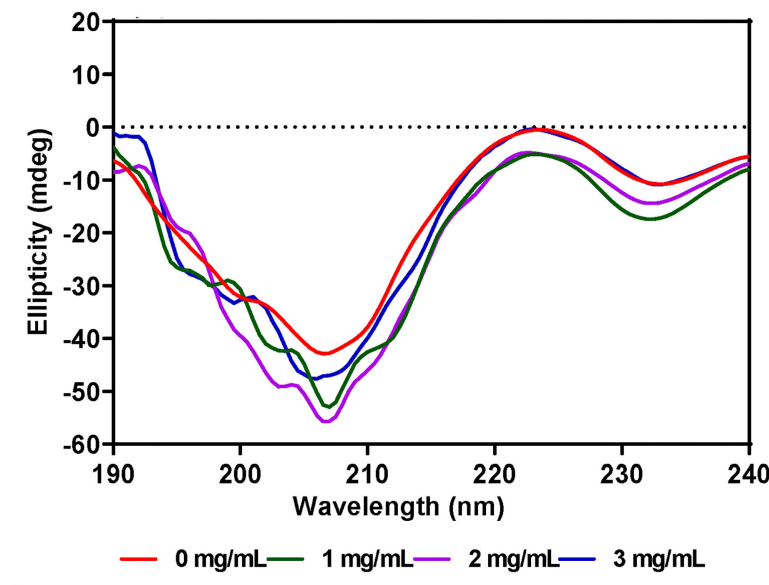

C

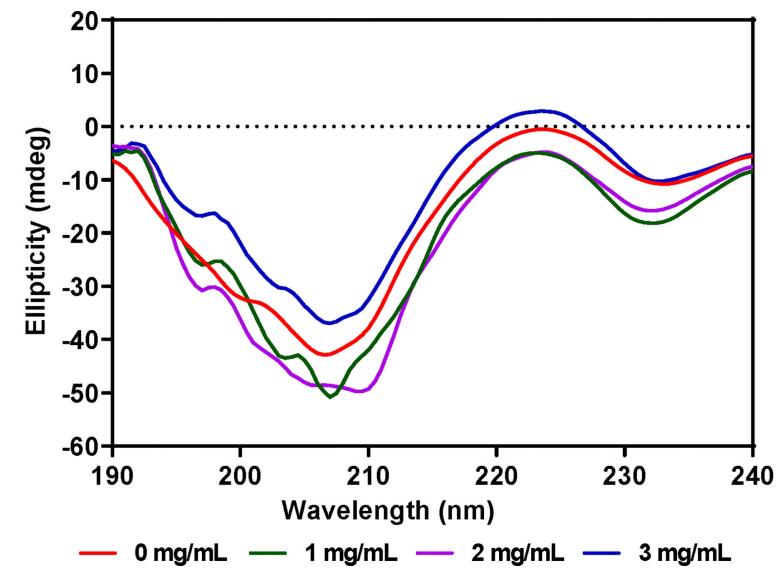

E

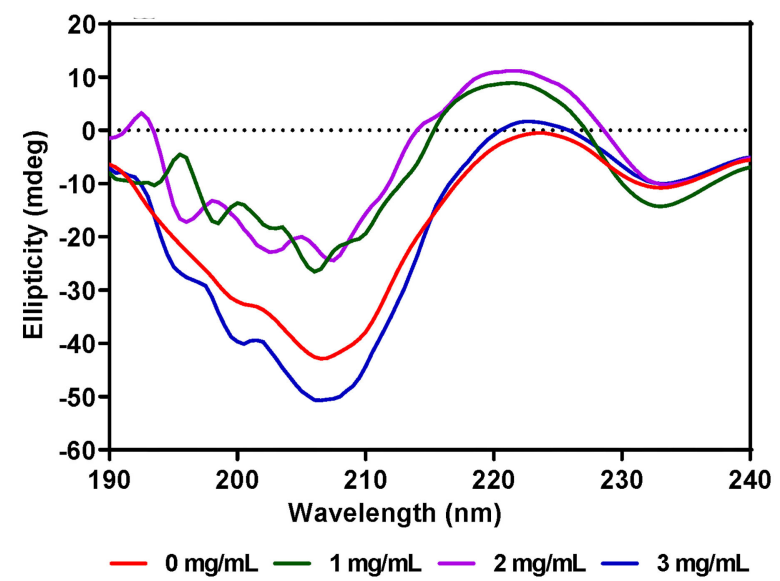

B

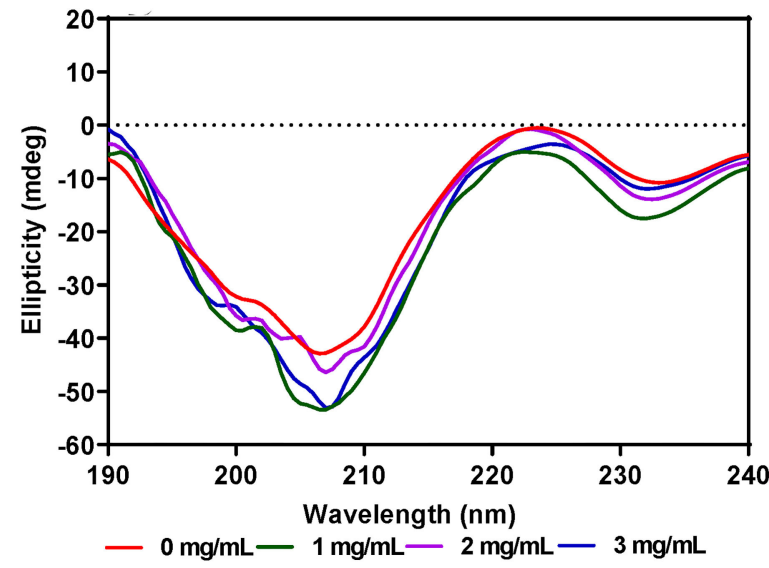

D

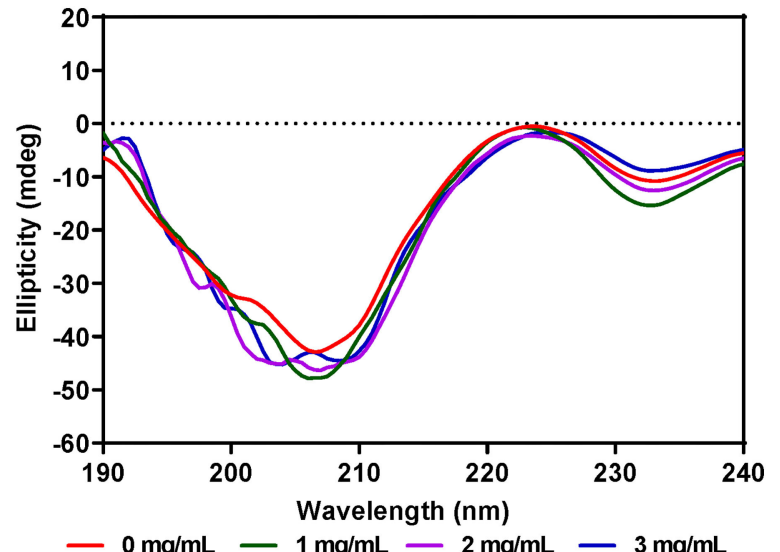

F

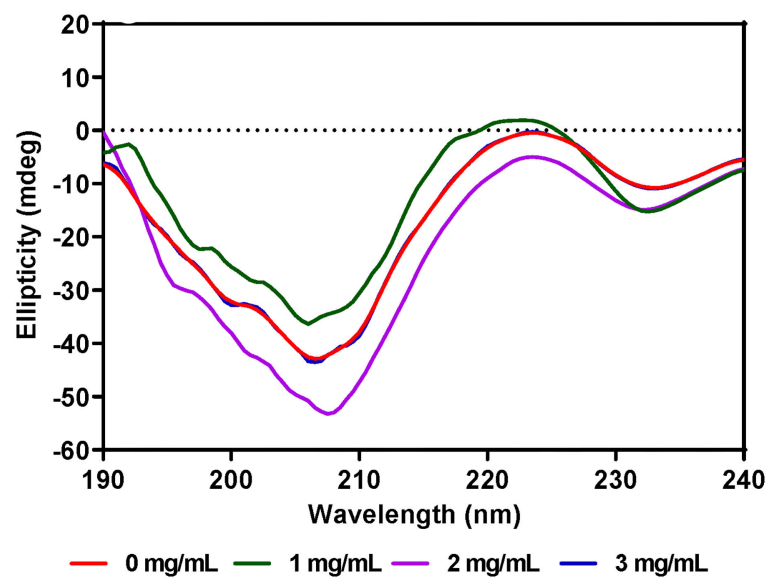

FIGURE 6 | Far-UV CD of pancreatic lipase in the presence of varied concentrations of leaf extracts from: (A) AV-40-T1, (B) AV-40-T2, (C) SM-40-T1, (D) SM-40-T2, (E) TO-40-T1, and (F) TO-40-T2. Plants were produced with nitrogen fertilizer (40 kg/ha), which was applied at (T1) or after (T2) planting.

that could have been responsible for the observed enzyme activity modulation. Based on fluorescence emission patterns, $\alpha$-amylase interactions with the extracts indicated shifting of aromatic groups to non-polar environments, which contrasted that of PL where the groups became exposed to hydrophilic environments. Therefore, mechanism of catalysis inhibition by the polyphenolic-rich leaf extracts was enzyme specific, but nitrogen fertilizer application led to decreased inhibitory 
A

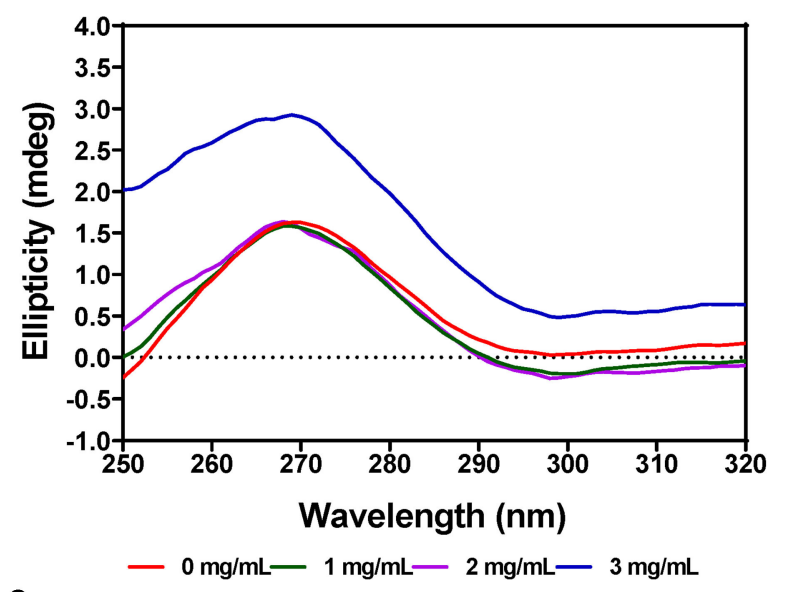

C

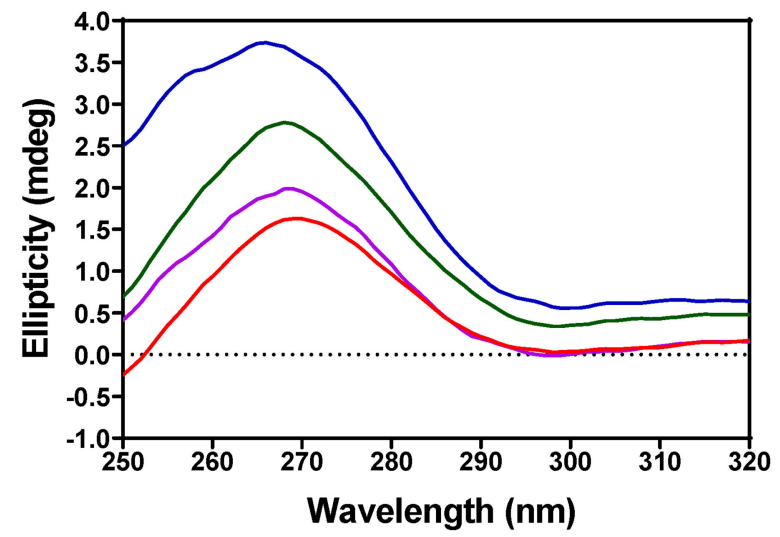

E
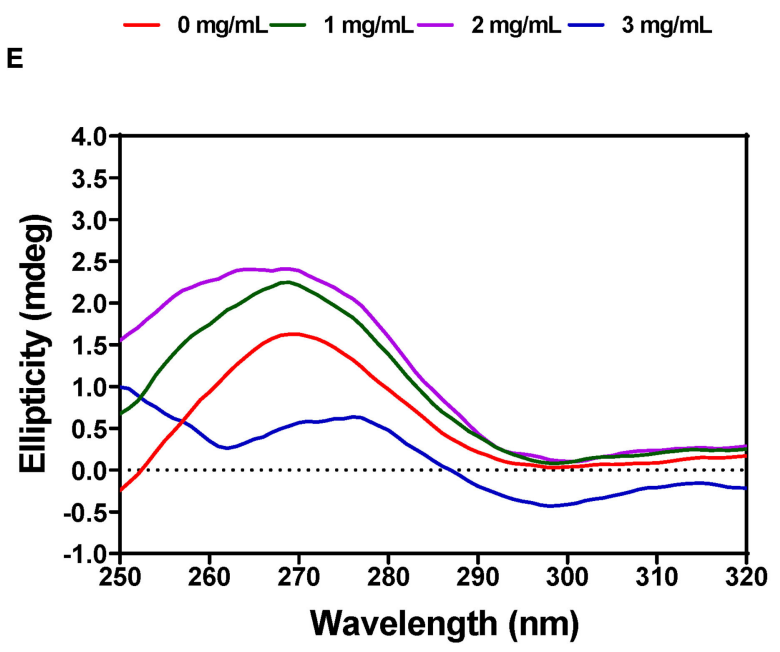

$-0 \mathrm{mg} / \mathrm{mL}-1 \mathrm{mg} / \mathrm{mL}-2 \mathrm{mg} / \mathrm{mL}-3 \mathrm{mg} / \mathrm{mL}$

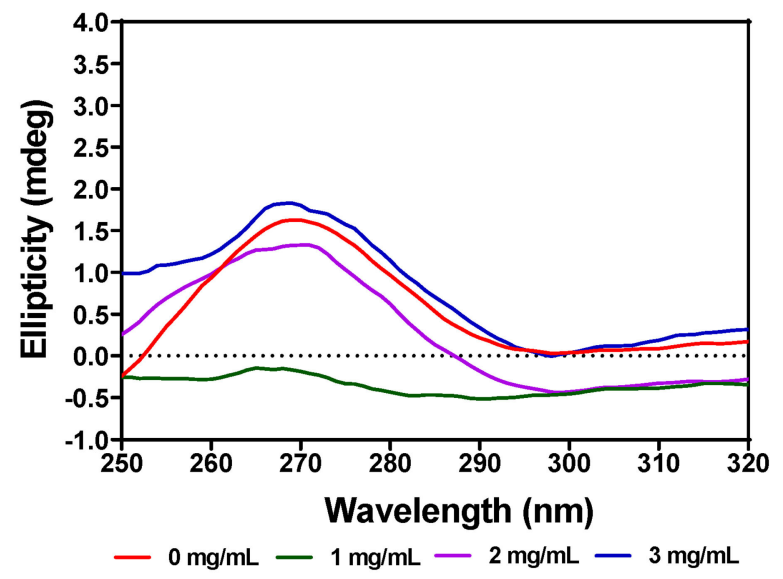

D

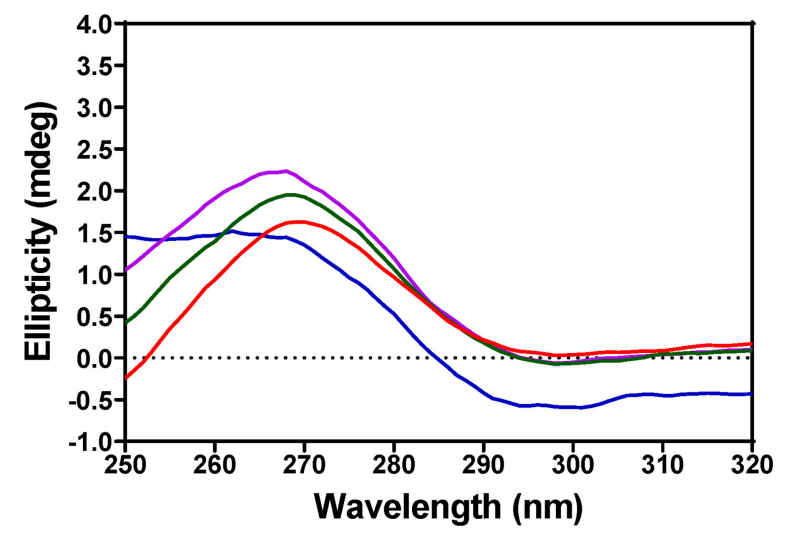

$-0 \mathrm{mg} / \mathrm{mL}-1 \mathrm{mg} / \mathrm{mL}-2 \mathrm{mg} / \mathrm{mL}-3 \mathrm{mg} / \mathrm{mL}$

$\mathbf{F}$

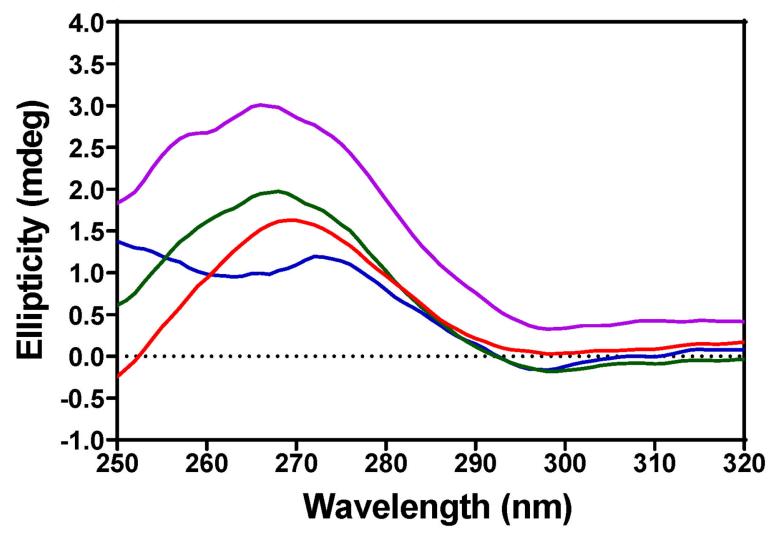

- $0 \mathrm{mg} / \mathrm{mL}-1 \mathrm{mg} / \mathrm{mL}-2 \mathrm{mg} / \mathrm{mL}-3 \mathrm{mg} / \mathrm{mL}$

FIGURE 7 | Near-UV CD of $\alpha$-amylase in the presence of varied concentrations of leaf extracts from: (A) AV-20-T1, (B) AV-20-T2, (C) SM-20-T1, (D) SM-20-T2, (E) TO-20-T1, and (F) TO-20-T2. Plants were produced with nitrogen fertilizer (20 kg N/ha), which was applied at (T1) or after (T2) planting.

efficacy of the leaf extracts against $\alpha$-amylase and PL. Hence the application of urea fertilizer may not be an efficient way of enhancing the enzyme-inhibitory activities of $\mathrm{AV}, \mathrm{SM}$, and
TO leaf polyphenolic extracts. Overall, the TO extracts had the strongest inhibitory effects, which were reflected in more extensive changes to the secondary and tertiary structures of 
A

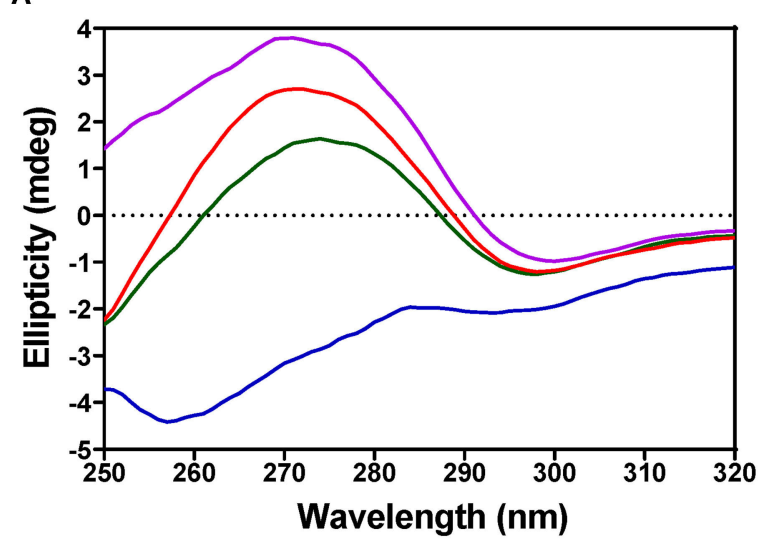

$-0 \mathrm{mg} / \mathrm{mL}-1 \mathrm{mg} / \mathrm{mL}-2 \mathrm{mg} / \mathrm{mL}-3 \mathrm{mg} / \mathrm{mL}$

C

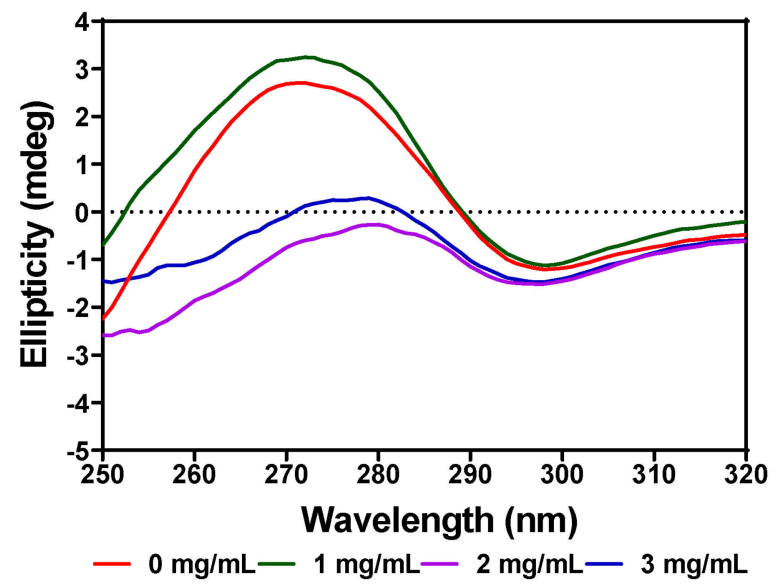

E

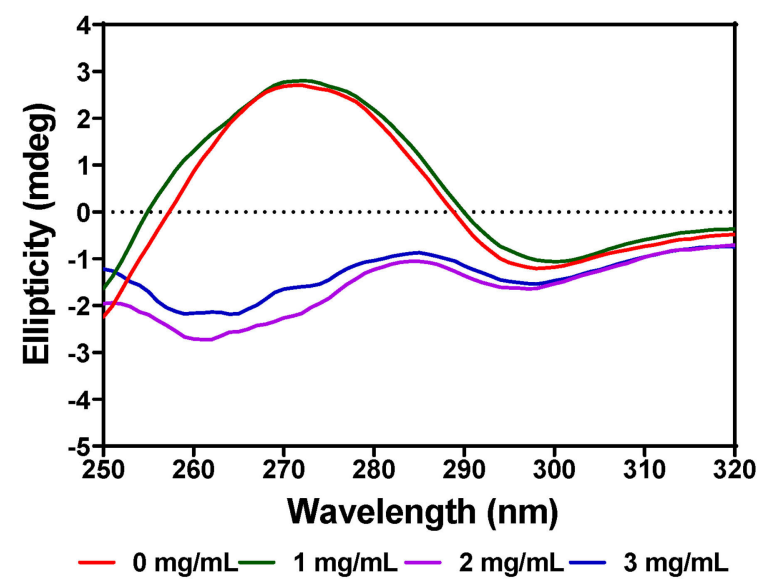

B

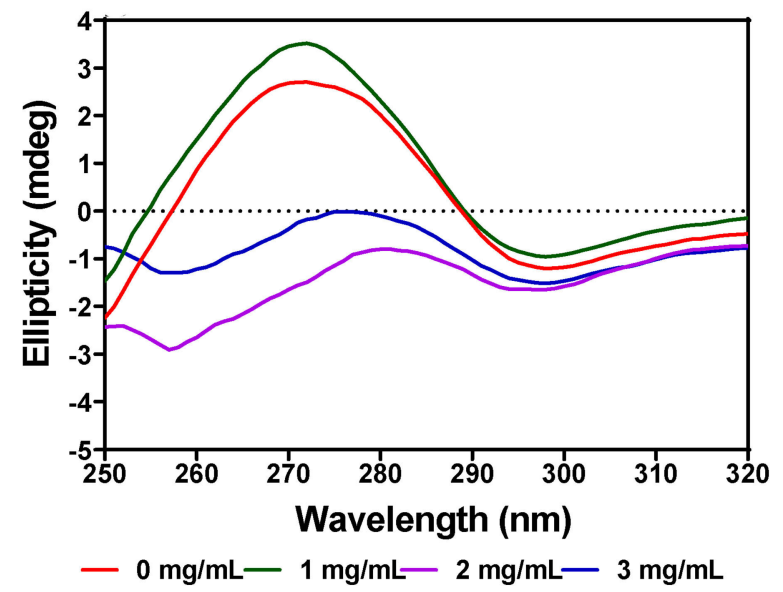

D

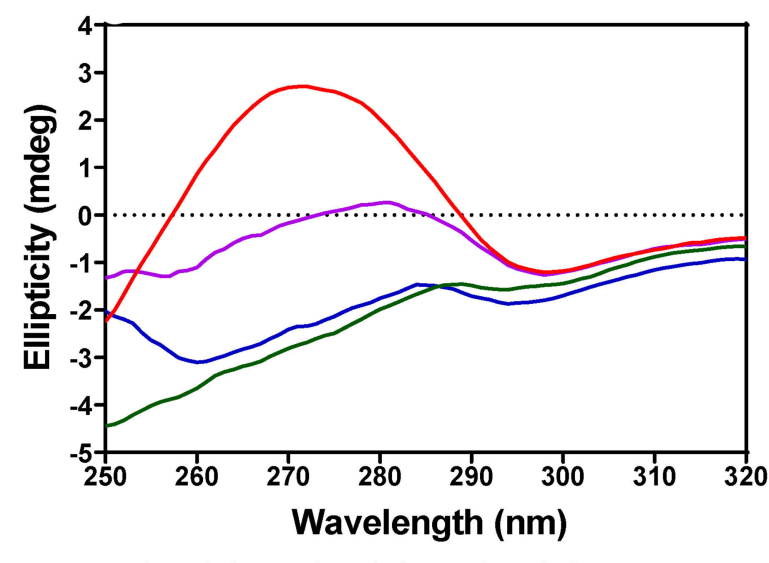

$\mathbf{F}$

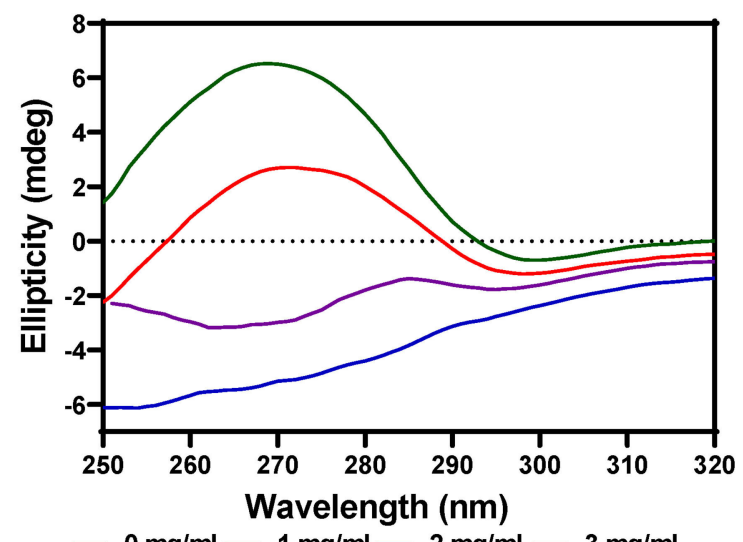

FIGURE 8 | Near-UV CD of pancreatic lipase in the presence of varied concentrations of leaf extracts from: (A) AV-40-T1, (B) AV-40-T2, (C) SM-40-T1, (D) SM-40-T2, (E) TO-40-T1, and (F) TO-40-T2. Plants were produced with nitrogen fertilizer (40 kg/ha), which was applied at (T1) or after (T2) planting.

the enzymes. Inhibitions against these two enzymes by the leaf extracts suggest their potential use as agents that could down regulate blood glucose through reduced intestinal digestion of nutrient polysaccharides and an additional suppression of calorie intake by reducing fat digestion. Therefore, consumption of these leaf extracts, especially TO may interfere with digestive 
functions that lead to reduced blood glucose and lipids, which could enable body weight control. However, animal and human feeding experiments are required to confirm these in vitro data. Moreover, additional studies are required to determine inhibition of glucose transporters 2, because of the potential competition between polyphenolic compounds and glucose for these bioreceptors.

\section{DATA AVAILABILITY STATEMENT}

The original contributions presented in the study are included in the article/supplementary material, further inquiries can be directed to the corresponding author/s.

\section{AUTHOR CONTRIBUTIONS}

RA: conceptualization, funding acquisition, and project administration. RA, AA, and OO: methodology. RA: resources.

\section{REFERENCES}

1. Santhiya N, Priyanga S, Hemmalakshmi S, Devaki K. Phytochemical analysis, anti inflammatory activity, in vitro antidiabetic activity and GCMS profile of Erythrina variegata L. bark. J App Pharm Sci. (2016) 6:147-55. doi: 10.7324/JAPS.2016.60722

2. Choudhury A, Maeda K, Murayama R, DiMagno EP. Character of a wheat amylase inhibitor preparation and effects on fasting human pancreaticobiliary secretions and hormones. Gastroenterology. (1996) 111:1313-20. doi: 10.1053/gast.1996.v111.pm88 98646

3. Nair SS, Kavrekar V, Mishra A. In vitro studies on alpha amylase and alpha glucosidase inhibitory activities of selected plant extracts. Eur J Exp Biol. (2013) 3:128-32. doi: 10.4103/0253-7613.1 61270

4. Sachan AK, Rao CV, Sachan NK. In vitro studies on the inhibition of $\alpha$ amylase and $\alpha$-glucosidase by hydro-ethanolic extract of Pluchea lanceolata, Alhagi pseudalhagi, Caesalpinia bonduc. Pharmacognosy Res. (2019) 11:310-4. doi: $10.4103 /$ pr.pr_31_19

5. Sultana R, Alashi AM, Islam K, Saifullah M, Haque CE, Aluko RE. Inhibitory activities of polyphenolic extracts of bangladeshi vegetables against $\alpha$-amylase, $\alpha$-glucosidase, pancreatic lipase, renin, and angiotensin-converting enzyme. Foods. (2020) 9:844. doi: 10.3390/foods9070844

6. Ademiluyi A, Oboh G, Ogunsuyi O. Oloruntoba F. A comparative study on antihypertensive and antioxidant properties of phenolic extracts from fruit and leaf of some guava (Psidium guajava L.) varieties. Comp Clin Pathol. (2016) 25:363-74. doi: 10.1007/s00580-015-2192-y

7. Chiang YC, Chen CL, Jeng TL. Sung JM. In vitro inhibitory effects of cranberry bean (Phaseolus vulgaris L.) extracts on aldose reductase, $\alpha$-glucosidase and $\alpha$-amylase. Int J Food Sci Technol. (2014) 49:1470-9. doi: 10.1111/ijfs. 12426

8. Chiou S-Y, Lai J-Y, Liao J-A, Sung J-M, Lin S-D. In vitro inhibition of lipase, $\alpha-$ amylase, $\alpha$-glucosidase, and angiotensin-converting enzyme by defatted rice bran extracts of red-pericarp rice mutant. Cereal Chem. (2018) 95:167-76. doi: $10.1002 /$ cche. 10025

9. Gondoin A, Grussu D, Stewart D, McDougall GJ. White and green tea polyphenols inhibit pancreatic lipase in vitro. Food Res Int. (2010) 43:1537-44. doi: 10.1016/j.foodres.2010.04.029

10. Cai S, Wang O, Wang M, He J, Wang Y, Zhang D, et al. Ji B. In vitro inhibitory effect on pancreatic lipase activity of subfractions from ethanol extracts of fermented Oats (Avena sativa L.) and synergistic effect of three phenolic acids. J Agric Food Chem. (2012) 60:7245-51. doi: 10.1021/jf3009958
OO: writing-original draft preparation. RA and AA: writingreview and editing. OO: formal analysis. RA and AA: supervision. All authors have read and agreed to the submitted version of the manuscript.

\section{FUNDING}

This research was funded by the International Development Research Center and Global Affairs Canada through the Canadian International Food Security Research Fund, Project 107983 on synergizing indigenous vegetables and fertilizer micro-dosing innovations among West African farmers.

\section{ACKNOWLEDGMENTS}

OO received the University of Manitoba Graduate Fellowship for Ph.D. studies.
11. McDougall GJ, Kulkarni NN, Stewart D. Berry polyphenols inhibit pancreatic lipase activity in vitro. Food Chem. (2009) 115:193-9. doi: 10.1016/j.foodchem.2008.11.093

12. Nakai M, Fukui Y, Asami S, Toyoda-Ono Y, Iwashita T, Shibata $\mathrm{H}$, et al. Inhibitory effects of oolong tea polyphenols on pancreatic lipase in vitro. J Agric Food Chem. (2005) 53:4593-8. doi: 10.1021/jf04 7814+

13. Rahim ATMA, Takahashi Y, Yamaki K. Mode of pancreatic lipase inhibition activity in vitro by some flavonoids and non-flavonoid polyphenols. Food Res Int. (2015) 75:289-94. doi: 10.1016/j.foodres.2015. 05.017

14. Lacroix IME, Li-Chan ECY. Inhibition of dipeptidyl peptidase (DPP)-IV and $\alpha$-glucosidase activities by pepsin-treated whey proteins. J Agric Food Chem. (2013) 61:7500-6. doi: 10.1021/jf40 $1000 \mathrm{~s}$

15. Awosika TO. Aluko RE. Inhibition of the in vitro activities of $\alpha$-amylase, $\alpha$-glucosidase and pancreatic lipase by yellow field pea (Pisum sativum L.) protein hydrolysates. Int J Food Sci Technol. (2019) 54:2021-34. doi: $10.1111 /$ ijfs. 14087

16. Shinde J, Taldone T, Barletta M, Kunaparaju N, Hu B, Kumar S, et al. $\alpha$ Glucosidase inhibitory activity of Syzygium cumini (Linn) Skeels seed kernel in vitro and in Goto-Kakizaki (GK) rats. Carbohydr Res. (2008) 343:1278-81. doi: 10.1016/j.carres.2008.03.003

17. Tysoe C, Williams LK, Keyzers R, Nguyen NT, Tarling C, Wicki $\mathrm{J}$, et al. Potent human alpha-amylase inhibition by the $\beta$-defensinlike protein helianthamide. ACS Central Sci. (2016) 2:154-61. doi: 10.1021/acscentsci.5b00399

18. Kim YS, Lee Y, Kim J, Sohn E, Kim CS, Lee YM, et al. Inhibitory activities of Cudrania tricuspidata leaves on pancreatic lipase in vitro and lipolysis in vivo. Evid Based Complement Alternat Med. (2012) 2012:878365. doi: $10.1155 / 2012 / 878365$

19. Seyedan A, Alshawsh MA, Alshagga MA, Koosha S, Mohamed Z. Medicinal plants and their inhibitory activities against pancreatic lipase: a review. Evid Based Complement Alternat Med. (2015) 2015:973143. doi: 10.1155/2015/973143

20. Siow HL, Choi SB, Gan CY. Structure-activity studies of protease activating, lipase inhibiting, bile acid binding and cholesterol-lowering effects of prescreened cumin seed bioactive peptides. J Funct Foods. (2016) 27:600-11. doi: 10.1016/j.jff.2016.10.013

21. Anhê FF, Desjardins Y, Pilon G, Dudonné S, Genovese MI, Lajolo FM, et al. Polyphenols and type 2 diabetes: a prospective review. PharmaNutrition. (2013) 1:105-14. doi: 10.1016/j.phanu.2013.07.004 
22. Pandey KB, Rizvi SI. Role of red grape polyphenols as antidiabetic agents. Integr Med Res. (2014) 3:119-25. doi: 10.1016/j.imr.2014.06.001

23. Patil P, Mandal S, Tomar SK, Anand S. Food protein-derived bioactive peptides in management of type 2 diabetes. Eur J Nutr. (2015) 54:863-80. doi: $10.1007 /$ s00394-015-0974-2

24. Schmid FX. Spectral methods of characterizing protein conformation and conformational changes. In: Creighton TE, editor. Protein Structure : A Practical Approach. Oxford: IRL Press (1989). p. 251-85. Available online at: https://eref.uni-bayreuth.de/14423/ (accessed April 27, 2021).

25. Eftink MR. Intrinsic fluorescence of proteins. In topics in fluorescence spectroscopy: volume 6: protein fluorescence. In: Lakowicz JR, editors. Topics in Fluorescence Spectroscopy. Boston, MA: Springer (2000). p. 1-15. ISBN 978-0-306-47102-5. doi: 10.1007/0-306-47102-7_1

26. Akhavan T, Ebrahimi M, Hekmat A. Structural evidence for kinetic and thermal stability changes of $\alpha$-amylase due to exposure to [emim] [lactate] ionic liquid. Turk J Biochem. (2020) 45:785-91. doi: 10.1515/tjb-2019-0270

27. Kelly SM, Jess TJ, Price NC. How to Study Proteins by Circular Dichroism. Biochimica et Biophysica Acta (BBA) - Proteins and Proteomics. (2005) 1751:119-39. doi: 10.1016/j.bbapap.2005.06.005

28. Bindraban PS, Dimkpa C, Nagarajan L, Roy A, Rabbinge R. Revisiting fertilisers and fertilisation strategies for improved nutrient uptake by plants. Biol Fertil Soils. (2015) 51:897-911. doi: 10.1007/s00374-015-1039-7

29. Moussa MID, Alashi AM, Sossa-Vihotogbé CNA, Akponikpè PBI, Baco MN, Djènontin $\mathrm{AJ}$, et al. Fertilizer micro-dosing and harvesting time of indigenous leafy vegetables affect in vitro antioxidant activities. J Food Bioactives. (2019) 6:118-30. doi: 10.31665/JFB.2019.6189

30. Olarewaju OA, Alashi AM, Taiwo KA, Oyedele D, Adebooye OC, Aluko RE. Influence of nitrogen fertilizer micro-dosing on phenolic content, antioxidant, and anticholinesterase properties of aqueous extracts of three tropical leafy vegetables. J Food Biochem. (2018) 42:e12566. doi: 10.1111/jfbc.12566

31. Tovihoudji PG, Akponikpè PBI, Adjogboto A, Djenontin JA, Agbossou EK, Bielders CL. Combining hill-placed manure and mineral fertilizer enhances maize productivity and profitability in northern Benin. Nutr Cycl Agroecosyst. (2018) 110:375-93. doi: 10.1007/s10705-017-9872-8

32. Filly A, Fabiano-Tixier AS, Louis C, Fernandez X, Chemat F. Water as a green solvent combined with different techniques for extraction of essential oil from lavender flowers. Comptes Rendus Chimie. (2016) 19:707-17. doi: 10.1016/j.crci.2016.01.018

33. Oboh G, Akinyemi A, Ademiluyi A. Inhibition of $\alpha$-amylase and $\alpha$ glucosidase activities by ethanolic extract of Telfairia occidentalis (fluted pumpkin) leaf. Asian Pac J Trop Biomed. (2012) 2:733-8. doi: 10.1016/S2221-1691(12)60219-6

34. Nwanna E. Inhibitory effects of methanolic extracts of two eggplant species from South-western Nigeria on starch hydrolysing enzymes linked to type-2 diabetes. Afr J Pharm Pharmacol. (2013) 7:1575-84. doi: 10.5897/AJPP2013.3606

35. Olarewaju OA, Alashi AM, Aluko RE. Antihypertensive effect of aqueous polyphenol extracts of Amaranthus viridis and Telfairia occidentalis leaves in spontaneously hypertensive rats. J Food Bioactives. (2018) 1:166-73. doi: 10.31665/JFB.2018.1135

36. Oluwagunwa O, Alashi A, Aluko R. Solanum macrocarpon leaf extracts reduced blood pressure and heart rate after oral administration to spontaneously hypertensive rats. Curr Top Nutraceutical Res. (2019) 17:28290. doi: 10.37290/ctnr2641-452X.17:282-290

37. Karakaya S, Gözcü S, Güvenalp Z, Özbek H, Yuca H, Dursunoglu B, et al. The $\alpha$-amylase and $\alpha$-glucosidase inhibitory activities of the dichloromethane extracts and constituents of Ferulago bracteata roots. Pharm Biol. (2018) 56:18-24. doi: 10.1080/13880209.2017.1414857

38. Tang Y, Zhang B, Li X, Chen PX, Zhang H, Liu R, et al. Bound phenolics of quinoa seeds released by acid, alkaline, and enzymatic treatments and their antioxidant and $\alpha$-glucosidase and pancreatic lipase inhibitory effects. J Agric Food Chem. (2016) 64:1712-9. doi: 10.1021/acs.jafc.5b05761

39. Erlanson C, Borgström B. Tributyrine as a substrate for determination of lipase activity of pancreatic juice and small intestinal content. Scand J Gastroenterol. (1970) 5:293-5. doi: 10.1080/00365521.1970.12096592

40. Li H, Aluko RE. Structural modulation of calmodulin and calmodulindependent protein kinase II by pea protein hydrolysates. Int J Food Sci Nutr. (2006) 57:178-89. doi: 10.1080/09637480600659144
41. Omoni AO, Aluko RE. Mechanism of the inhibition of calmodulin-dependent neuronal nitric oxide synthase by flaxseed protein hydrolysates. $\mathrm{J}$ Am Oil Chemists' Soc. (2006) 83:335-40. doi: 10.1007/s11746-006-1209-8

42. Andrews M, Raven JA, Lea PJ. Do plants need nitrate? The mechanisms by which nitrogen form affects plants. Ann Appl Biol. (2013) 163:174-99. doi: 10.1111/aab.12045

43. Becker C, Urlić B, Špika MJ, Kläring H-P, Krumbein A, Baldermann $\mathrm{S}$, et al. Nitrogen limited red and green leaf lettuce accumulate flavonoid glycosides, caffeic acid derivatives, and sucrose while losing chlorophylls, B-carotene and xanthophylls. PLoS ONE. (2015) 10:e0142867. doi: 10.1371/journal.pone.0142867

44. Prinsi B, Negrini N, Morgutti S, Espen L. Nitrogen starvation and nitrate or ammonium availability differently affect phenolic composition in green and purple basil. Agronomy. (2020) 10:498. doi: 10.3390/agronomy10040498

45. Kiferle C, Maggini R. Pardossi A. Influence of nitrogen nutrition on growth and accumulation of rosmarinic acid in sweet basil (Ocimum basilicum L.) grown in hydroponic culture. Aust J Crop Sci. (2013) 7:321-7.

46. Jakovljević D, Topuzović M, Stanković M. Nutrient limitation as a tool for the induction of secondary metabolites with antioxidant activity in basil cultivars. Ind Crops Prod. (2019) 138:111462. doi: 10.1016/j.indcrop.2019.06.025

47. Elhanafi L, Houhou M, Rais C, Mansouri I, Elghadraoui L, Greche H. Impact of excessive nitrogen fertilization on the biochemical quality, phenolic compounds, and antioxidant power of Sesamum indicum L. seeds. J Food Qual. (2019) 2019:e9428092. doi: 10.1155/2019/9428092

48. Radušiene J, Marksa M, Ivanauskas L, Jakštas V, Çalişkan Ö, Kurt D, et al. Effect of nitrogen on herb production, secondary metabolites and antioxidant activities of Hypericum pruinatum under nitrogen application. Ind Crops Prod. (2019) 139:111519. doi: 10.1016/j.indcrop.2019.1 11519

49. Sales PM, Souza PM, Simeoni LA, Magalhães PO, Silveira D. $\alpha$-Amylase inhibitors: a review of raw material and isolated compounds from plant source. J Pharm Pharm Sci. (2012) 15:141-83. doi: 10.18433/J35S3K

50. Jaradat N, Zaid A, Hussein F, Zaqzouq M, Aljammal H, Ayesh O. Anti-lipase potential of the organic and aqueous extracts of ten traditional edible and medicinal plants in palestine; a comparison study with orlistat. Medicines. (2017) 4:89. doi: 10.3390/medicines4040089

51. Bustanji Y, Mohammad M, Hudaib M, Tawaha K, Almasri I, Alkhatib H, et al. Screening of some medicinal plants for their pancreatic lipase inhibitory potential. Jordan J Pharm Sci. (2011) 4:81-8.

52. Teixeira LS, Lima AS, Boleti APA, Lima AAN, Libório ST, de Paula $\mathrm{L}$, et al. Effects of Passiflora nitida Kunth leaf extract on digestive enzymes and high caloric diet in rats. J Nat Med. (2014) 68:316-25. doi: 10.1007/s11418-013-0800-1

53. Soares S, Mateus N, De Freitas V. Interaction of different polyphenols with Bovine Serum Albumin (BSA) and Human Salivary $\alpha$-Amylase (HSA) by fluorescence quenching. J Agric Food Chem. (2007) 55:6726-35. doi: $10.1021 /$ jf $070905 \mathrm{x}$

54. Feng $\mathrm{H}$, Jin $\mathrm{H}$, Gao $\mathrm{Y}$, Zhu $\mathrm{X}$, Zhao $\mathrm{Q}$, Liu $\mathrm{C}$, et al. The effect of (-)-epigallocatechin-3-gallate non-covalent interaction with the glycosylated protein on the emulsion property. Polymers. (2019) 11:1688. doi: 10.3390/polym111 01688

55. Skrt M, Benedik E, Podlipnik C, Ulrih NP. Interactions of different polyphenols with bovine serum albumin using fluorescence quenching and molecular docking. Food Chem. (2012) 135:2418-24. doi: 10.1016/j.foodchem.2012.06.114

56. Sun L, Chen W, Meng Y, Yang X, Yuan L, Guo Y. Interactions between polyphenols in thinned young apples and porcine pancreatic $\alpha$-amylase: inhibition, detailed kinetics and fluorescence quenching. Food Chem. (2016) 208:51-60. doi: 10.1016/j.foodchem.2016.03.093

57. Zheng Y, Yang W, Sun W, Chen S, Liu D, Kong X, et al. Inhibition of porcine pancreatic $\alpha$-amylase activity by chlorogenic acid. J Funct Foods. (2020) 64:103587. doi: 10.1016/j.jff.2019.103587

58. Martinez-Gonzalez AI, Alvarez-Parrilla E, Díaz-Sánchez ÁG. de la Rosa LA, Núñez-Gastélum JA, Vazquez-Flores AA, et al. In vitro inhibition of pancreatic lipase by polyphenols: a kinetic, fluorescence spectroscopy and molecular docking study. Food Technol Biotechnol. (2017) 55:519-30. doi: $10.17113 / \mathrm{ftb} .55 .04 .17 .5138$ 
59. Yadav J, Prakash V. Stabilization of $\alpha$-amylase, the key enzyme in carbohydrates properties alterations, at low pH. Int J Food Prop. (2011) 14:1182-96. doi: 10.1080/10942911003592795

60. Ijarotimi OS, Malomo SA, Fagbemi TN, Osundahunsi OF, Aluko RE. Structural and functional properties of Buchholzia coriacea seed flour and protein concentrate at different $\mathrm{pH}$ and protein concentrations. Food Hydrocoll. (2018) 74:275-88. doi: 10.1016/j.foodhyd.2017.08.018

61. Martinez-Gonzalez AI, Díaz-Sánchez ÁG, De La Rosa LA, Vargas-Requena CL, Bustos-Jaimes I, Alvarez-Parrilla E. Polyphenolic compounds and digestive enzymes: in vitro non-covalent interactions. Molecules. (2017) 22:669. doi: 10.3390/molecules22040669

62. Li Y-Q, Yang P, Gao F, Zhang Z-W, Wu B. Probing the interaction between 3 flavonoids and pancreatic lipase by methods of fluorescence spectroscopy and enzymatic kinetics. Eur Food Res Technol. (2011) 233:63-9. doi: 10.1007/s00217-011-1491-z

63. Gonçalves R, Mateus N, de Freitas V. Study of the interaction of pancreatic lipase with procyanidins by optical and enzymatic methods. J Agric Food Chem. (2010) 58:11901-6. doi: 10.1021/jf103026x

64. Nasri R, Bidel LPR, Rugani N, Perrier V, Carrière F, Dubreucq E, et al. Inhibition of CpLIP2 lipase hydrolytic activity by four flavonols (galangin, kaempferol, quercetin, myricetin) compared to orlistat and their binding mechanisms studied by quenching of fluorescence. Molecules. (2019) 24:2888. doi: $10.3390 /$ molecules 24162888

65. Ghosh S, More P, Derle A, Patil AB, Markad P, Asok A, et al. Diosgenin from Dioscorea bulbifera: novel hit for treatment of type II diabetes mellitus with inhibitory activity against $\alpha$-amylase and $\alpha$-glucosidase. PLOS ONE. (2014) 9:e106039. doi: 10.1371/journal.pone.0106039

66. Roy D, Dutta S, Maity SS, Ghosh S, Singha Roy A, Ghosh KS, et al. Spectroscopic and docking studies of the binding of two stereoisomeric antioxidant catechins to serum albumins. J Lumin. (2012) 132:1364-75. doi: 10.1016/j.jlumin.2011.12.063

67. Wei Z, Yang W, Fan R, Yuan F, Gao Y. Evaluation of structural and functional properties of protein-EGCG complexes and their ability of stabilizing a model $\beta$-carotene emulsion. Food Hydrocoll. (2015) 45:337-50 doi: 10.1016/j.foodhyd.2014.12.008

68. Rawel HM, Czajka D, Rohn S, Kroll J. Interactions of different phenolic acids and flavonoids with soy proteins. Int J Biol Macromol. (2002) 30:137-50. doi: 10.1016/S0141-8130(02)00016-8

69. Rawel HM, Meidtner K, Kroll J. Binding of selected phenolic compounds to proteins. J Agric Food Chem. (2005) 53:4228-35. doi: 10.1021/jf04 80290

70. Gupta S, Mahmood S, Khan RH, Mahmood A. Inhibition of brush border sucrase by polyphenols in mouse intestine. Biosci Rep. (2010) 30:111-7. doi: 10.1042/BSR20090012

71. Kroll J, Rawel HM, Rohn S. Reactions of plant phenolics with food proteins and enzymes under special consideration of covalent bonds. Food Sci Technol Res. (2003) 9:205-18. doi: 10.3136/fstr.9.205

Conflict of Interest: The authors declare that the research was conducted in the absence of any commercial or financial relationships that could be construed as a potential conflict of interest.

Publisher's Note: All claims expressed in this article are solely those of the authors and do not necessarily represent those of their affiliated organizations, or those of the publisher, the editors and the reviewers. Any product that may be evaluated in this article, or claim that may be made by its manufacturer, is not guaranteed or endorsed by the publisher.

Copyright (c) 2021 Oluwagunwa, Alashi and Aluko. This is an open-access article distributed under the terms of the Creative Commons Attribution License (CC BY). The use, distribution or reproduction in other forums is permitted, provided the original author(s) and the copyright owner(s) are credited and that the original publication in this journal is cited, in accordance with accepted academic practice. No use, distribution or reproduction is permitted which does not comply with these terms. 